Article

\title{
An Integrated Multi-Criteria Decision Support Framework for the Selection of Suppliers in Small and Medium Enterprises based on Green Innovation Ability
}

\author{
Almalki Sultan Musaad O ${ }^{1, *} \mathbb{*}$, Zhang Zhuo ${ }^{1}$, Zafar Ali Siyal ${ }^{2}$, Ghulam Muhammad Shaikh ${ }^{3}(\mathbb{D}$, \\ Syed Ahsan Ali Shah ${ }^{1,4}$, Yasir Ahmed Solangi ${ }^{1,4, *}$ (i) and Almalki Otaibi Musaad $O{ }^{1,5}$ \\ 1 College of Economics and Management, Nanjing University of Aeronautics and Astronautics, \\ Nanjing 211106, China; petazhzh@126.com (Z.Z.); ahsan.shah@nuaa.edu.cn or \\ ahsan.shah1@hotmail.com (S.A.A.S.); swalify118@gmail.com (A.O.M.O.) \\ 2 Department of Energy and Environment Engineering, Quaid-e-Awam University of Engineering, Science \\ and Technology, Nawabshah 67480, Pakistan; zafarsiyal@quest.edu.pk \\ 3 Department of Computer Science, Bahria University, Karachi 75260, Pakistan; \\ ghulammuhammad.bukc@bahria.edu.pk \\ 4 School of Economics and Management, Nanjing University of Science and Technology, \\ Nanjing 210094, China \\ 5 College of Business Administration, Taif University, Taif 11099, Saudi Arabia \\ * Correspondence: susulin@nuaa.edu.cn (A.S.M.O.); yasir.solangi@nuaa.edu.cn or \\ yasir.solangi86@hotmail.com (Y.A.S.)
}

Received: 10 March 2020; Accepted: 27 March 2020; Published: 1 April 2020

\begin{abstract}
Globally, organizations are under enormous pressure to implement green supply chain processes due to growing environmental concerns. Subsequently, organizations and firms have become more conscious of their suppliers' green innovation ability. However, the selection of the most optimum supplier concerning green innovation ability remains a challenging task that needs to be analyzed. Thus, this study develops an integrated fuzzy and grey-based methodology to analyze and prioritize suppliers for small and medium enterprises (SMEs) in the context of Saudi Arabia. Initially, the study identifies 4 criteria and 20 sub-criteria through extensive literature review with respect to suppliers' green innovation ability. Later, the Fuzzy Analytical Hierarchy Process (AHP) computes weights of criteria and sub-criteria. Finally, the Technique for Order of Preference by Similarity to Ideal Solution (TOPSIS)-Grey was employed to rank the suppliers. The process of assigning weights to criteria and sub-criteria involved twelve experts from academics and industry. The results of Fuzzy AHP indicated that the "Green Innovation Initiatives" is the most significant criterion for the supplier selection. The results of TOPSIS-Grey revealed that the "Supplier-3" is the most optimum supplier having the highest potential of adopting green practices among other suppliers. The overall results provide adequate feedback for organizations and firms to maximize their ability to curb environmental impacts from their upstream activities.
\end{abstract}

Keywords: supplier selection; green innovation; SMEs; Fuzzy AHP; TOPSIS-Grey; Saudi Arabia

\section{Introduction}

The world is experiencing natural resource depletion at a rapid rate that is due to increasing rates of industrialization, population, and urbanization [1]. Numerous steps have been taken to lower this depletion rate across the world. For instance, governments and environmental agencies have been seeking efficient ways of resource utilization and shifting towards alternative sources that can be 
naturally replenished. The increasing globalization has its adverse implications on the environment, for instance, a surge in industrialization intensifies industrial waste and greenhouse gas emissions (GHGs), which are hazardous for the environment [2]. Nowadays, industries are under a great deal of pressure from environmental activists to implement sustainable supply chain practices during the whole process of production. Organizations all over the world, especially small and medium enterprises (SMEs), have an essential role to play in economic growth. However, they also generate a significant amount of GHGs to pollute the environment [3]. Thus, governments and various environmental agencies have focused on this issue and introduced strict policies for organizations to minimize activities responsible for environmental degradation.

During the annual conference, the Intergovernmental Panel on Climate Change (IPCC) [4] held manufacturing industries accountable for creating environmental problems such as resource depletion, environmental pollution, climate change, and global warming. The IPCC provided directions to governments and responsible agencies across the world to move towards clean, innovative, and green technologies, and cease traditional manufacturing and production practices. In 2016, the United Nations (UN) called a meeting aiming to adopt sustainable development practices by 2030 [5]. During that meeting, the UN identified 17 goals for sustainable development in a variety of areas from poverty alleviation, education, health, job opportunities, social protection, and environmental protection to climate change. Among these goals, goal number twelve focuses explicitly on achieving and enabling a sustainable environment, reducing environmental polluting activities, and implementing sustainable consumption and production activities in organizations [6]. Moreover, the goal compels organizations to transform their conventional supply chains into greener supply chains to achieve sustainable development in organizations [7].

Presently, industries have recognized this issue and therefore tend to switch to green supply chains by adopting green and sustainable practices from upstream to downstream operations. It is a mutual responsibility of organizations and industries to dedicatedly contribute to the accomplishment of sustainable development goals [8]. Therefore, organizations have to make sudden changes in the operational structure to make it more sustainable. However, shutting the existing system and making huge changes remains a massive challenge for organizations. To effectively deal with this challenge, organizations must seek and introduce new ways for sustainable product manufacturing and designing. Also, new initiatives have to be taken for waste disposal, which do not affect the environment. In this regard, green innovation can be a vital tool for organizations to use for releasing environmental pressure posed upon them by regulators, stakeholders, and nowadays customers as well since, due to increasing environmental awareness, customers demand organizations to be environmentally-friendly [9]. The green innovation comprises both industry manufacturing processes and product innovation. Supply chain processes generate a larger portion of industrial waste. Therefore, it is a core area for organizations to work on to avoid any pressure from environmental activists and agencies. Organizations may focus on integrating their activities with suppliers by implementing an environmental management system and organizing environmental training programs and technical assistance to enhance the performance of suppliers. Industries like SMEs must invest in selecting the greener supplier by implementing the green innovation criteria and meet the requirements and standards of the customers and regulators for a sustainable supply chain process.

The selection of suppliers based on green innovation activities remains challenging for SMEs as the process involves complexities and multi-criteria for selection. In this study, we have proposed a framework which can enable SMEs to prioritize criteria for supplier selection and then rank suppliers based on prioritized criteria. The study develops an integrated multi-criteria decision making (MCDM) methods, i.e., Fuzzy Analytical Hierarchy Process (AHP) and Technique for Order of Preference by Similarity to Ideal Solution (TOPSIS)-Grey methods to evaluate, select, and rank suppliers for SMEs based on green innovation criteria. To the best of our knowledge, this is a new kind of study which analyzes the green innovation criteria for the selection of SMEs' suppliers using above-stated MCDM methods. This decision problem is undertaken in the context of Saudi Arabia. In this research, the 
Fuzzy AHP method is utilized to analyze and prioritize green innovation criteria and sub-criteria for SMEs. The fuzzy set theory helps in removing any uncertainty and fuzziness of the decision problem since experts' decision-making may have some human errors.

Moreover, TOPSIS-Grey methodology is employed to prioritize suppliers based on identified green innovation criteria from the Fuzzy AHP method. The developed decision model helps in fulfilling the objective of the study by identifying green innovation criteria for SMEs and supplier selection in the selected SMEs based on green innovation activities. Therefore, this research may help in determining the most feasible supplier among various SMEs in implementing green supply chain management (SCM) practices.

The rest of the paper outlines as follows: Section 2 reviews more recent and relevant studies conducted for the decision-making related to supplier selection. Section 3 introduces MCDM methods used in this study and then present the proposed integrated methodology. Section 4 contains analysis, results of the study, and discussion. Section 5 concludes the study.

\section{Literature Review}

Green innovation defines as the innovative approaches taken by organizations to transform their conventional practices into greener to mitigate adverse environmental implications of organizational activities and to accomplish sustainable environmental targets [10]. Green innovation can help organizations minimize the ecological danger, air pollution, climate change, and other harmful environmental implications through green SCM [11,12]. Any organization which uses green practices in their supply chain operations has a good advantage in the market and thus can quote high prices for their eco-friendly products and can also enter the new market very quickly [13]. Many researchers around the world have studied various aspects of green innovation to transforms the SME's practices into sustainable SCM $[14,15]$. This section provides a thorough review of the most relevant studies conducted in the context of sustainable supplier selection. Firstly, the section reviews studies that applied MCDM for supplier selection related decision-making and then sort out criteria and sub-criteria to evaluate suppliers considered in this study.

\subsection{Related Studies Based on MCDM Methodologies}

MCDM techniques are considered to be very crucial in solving any decision-problem [16-18]. Several MCDM methods have been employed in previous studies for suppliers' evaluation and ranking based on green innovation practices [19]. A few critical studies on green supplier selection are listed in Table 1.

Table 1. The past studies on the selection of green suppliers for SMEs.

\begin{tabular}{|c|c|c|c|c|}
\hline Research Focus & Research Findings & Method & Year & Reference \\
\hline $\begin{array}{l}\text { Sustainable supplier } \\
\text { selection for an } \\
\text { automobile company } \\
\text { in India }\end{array}$ & $\begin{array}{l}\text { In this research, it is revealed that } \\
\text { environmental costs, product quality, and } \\
\text { product price are three top-ranking } \\
\text { criteria for the selection of a sustainable } \\
\text { supplier. }\end{array}$ & $\begin{array}{c}\text { Analytical } \\
\text { Hierarchy Process } \\
\text { (AHP) and } \\
\text { Kriterijumska } \\
\text { Optimizacija I } \\
\text { Kompromisno } \\
\text { Resenje (VIKOR) }\end{array}$ & 2017 & [20] \\
\hline $\begin{array}{l}\text { Supplier selection } \\
\text { within a food supply } \\
\text { chain context }\end{array}$ & $\begin{array}{l}\text { Research findings show that price is the } \\
\text { most significant criterion for supplier } \\
\text { selection. }\end{array}$ & $\begin{array}{l}\text { Best Worst method } \\
\text { (BWM) }\end{array}$ & 2016 & [21] \\
\hline $\begin{array}{l}\text { Evaluating the green } \\
\text { supplier growth } \\
\text { program }\end{array}$ & $\begin{array}{l}\text { The results of this study show that ISO } \\
14000 \text { certification is a feasible alternative } \\
\text { for a greener supplier development } \\
\text { program. }\end{array}$ & $\begin{array}{l}\text { Normal Group } \\
\text { Technique (NGT) } \\
\text { and VIKOR }\end{array}$ & 2016 & [22] \\
\hline
\end{tabular}


Table 1. Cont.

\begin{tabular}{|c|c|c|c|c|}
\hline Research Focus & Research Findings & Method & Year & Reference \\
\hline $\begin{array}{l}\text { Green supplier } \\
\text { selection for Iranian } \\
\text { automotive company }\end{array}$ & $\begin{array}{l}\text { This study reveals that economic criteria } \\
\text { are preferable than environmental criteria; } \\
\text { whereas, the cost is a more critical } \\
\text { sub-criterion than technology and quality } \\
\text { for analyzing the green supplier. }\end{array}$ & $\begin{array}{c}\text { Analytical } \\
\text { Hierarchy Process } \\
\text { (ANP) and Grey } \\
\text { Relational Analysis } \\
\text { (GRA) }\end{array}$ & 2015 & [23] \\
\hline $\begin{array}{l}\text { the green supplier } \\
\text { selection in the } \\
\text { electronics industry }\end{array}$ & $\begin{array}{l}\text { Results present that current capacity and } \\
\text { R\&D capability are vital criteria for the } \\
\text { selection of a green supplier in the } \\
\text { electronics industry. }\end{array}$ & $\begin{array}{c}\text { AHP and } \\
\text { ELimination Et } \\
\text { Choice Translating } \\
\text { REality } \\
\text { (ELECTRE)-III }\end{array}$ & 2014 & [24] \\
\hline $\begin{array}{l}\text { Supplier selection for } \\
\text { carbon management } \\
\text { in green SCM }\end{array}$ & $\begin{array}{l}\text { The findings indicate that the } \\
\text { management system of carbon and } \\
\text { training related to carbon management } \\
\text { are the most important criteria for } \\
\text { selecting a supplier. }\end{array}$ & $\begin{array}{l}\text { Decision making } \\
\text { trial and evaluation } \\
\text { laboratory } \\
\text { (DEMATEL) }\end{array}$ & 2013 & [25] \\
\hline $\begin{array}{l}\text { Assessing suppliers } \\
\text { for green } \\
\text { development } \\
\text { program in the } \\
\text { automobile industry }\end{array}$ & $\begin{array}{l}\text { The findings of this study show that } \\
\text { quality, preventing pollution, and green } \\
\text { image are the most necessary criteria for } \\
\text { supplier selection to include green } \\
\text { development programs. }\end{array}$ & $\begin{array}{c}\text { Fuzzy c-means and } \\
\text { VIKOR }\end{array}$ & 2015 & [26] \\
\hline $\begin{array}{l}\text { The green supplier } \\
\text { selection for a textile } \\
\text { industry }\end{array}$ & $\begin{array}{l}\text { The analysis of this study shows that } \\
\text { quality is a preferable criterion followed } \\
\text { respectively by green product and cost for } \\
\text { the supplier selection. }\end{array}$ & Fuzzy AHP & 2019 & [27] \\
\hline $\begin{array}{l}\text { Green supplier } \\
\text { selection for Indian } \\
\text { cement industry }\end{array}$ & $\begin{array}{l}\text { The research findings present that safety, } \\
\text { quality, and cost are crucial criteria for } \\
\text { selecting a green supplier in the cement } \\
\text { industry. }\end{array}$ & AHP & 2016 & [28] \\
\hline $\begin{array}{l}\text { Supplier selection for } \\
\text { the agri-food industry }\end{array}$ & $\begin{array}{l}\text { The analysis indicates that service level is } \\
\text { the most important criterion for the green } \\
\text { supplier selection. }\end{array}$ & $\begin{array}{c}\text { Fuzzy TOPSIS, } \\
\text { Fuzzy VIKOR, and } \\
\text { Fuzzy GRA }\end{array}$ & 2018 & [29] \\
\hline
\end{tabular}

It is identified that various studies are related to the supplier selection for green SCM activities of SMEs. In these existing studies, the authors have evaluated different vital criteria for the selection of green suppliers using numerous MCDM methods. This study further contributes to the literature and proposes an integrated decision model, i.e., Fuzzy AHP and TOPSIS-Grey methodology to assess and rank suppliers based on green innovation criteria of the SMEs in the context of Saudi Arabia.

\subsection{Proposed Green Innovation Criteria in the Study}

In this research, a comprehensive literature review was conducted to identify and analyze various critical green innovation criteria and sub-criteria about the selection of suppliers based on the implementation of green supply chain practices. The study picks four green innovation criteria from existing studies. These criteria include green innovation capacity (A), green innovation initiatives (B), green innovation performance (C), and green innovation monitoring and follow-up (D). Table 2 shows a list of green innovation criteria and sub-criteria used in this study.

It is identified that many studies have researched supplier selection problems for implementing greener practices in the supply chain process. These studies, as mentioned above, have focused on the supplier selection in respect of green activities and based on significant criteria for green supply chain activities in organizations. Moreover, it is identified from Table 1 that in the existing studies, the authors used various multi-criteria decision methodologies individually or by integrated two or more techniques. The proposed method in this study reduces uncertainty in the decision-making more proficiently as it combines fuzzy set theory and grey theory with the most acclaimed MCDM 
models. Therefore, in the study, we have proposed integrated multi-criteria applications based on Fuzzy AHP and TOPSIS-Grey for green supplier selection in the context of Saudi Arabia concerning green innovation activities. To the best of authors' knowledge, this study is unique and novel in terms of identifying green innovation criteria for the supplier selection using Fuzzy AHP and TOPSIS-Grey methodology.

Table 2. Green innovation criteria and sub-criteria for the study.

\begin{tabular}{|c|c|c|}
\hline Criteria & Sub-Criteria & Reference \\
\hline \multirow{5}{*}{ Green innovation capacity (A) } & Supplier's economic competitiveness (A1) & [30-33] \\
\hline & Capacity of supplier's general innovation (A2) & {$[20,32,34,35]$} \\
\hline & Awareness about sustainability management (A3) & {$[12,35,36]$} \\
\hline & Trained human resources (A4) & {$[12,20,33]$} \\
\hline & Production efficiency (A5) & {$[35,37,38]$} \\
\hline \multirow{5}{*}{ Green innovation initiatives (B) } & Share of renewable energy utilization (B1) & {$[39,40]$} \\
\hline & Energy efficiency and conservation (B2) & {$[29,39]$} \\
\hline & Green transportation (B3) & {$[12,20,22,41]$} \\
\hline & Green recycling (B4) & {$[12,20,22,41]$} \\
\hline & Green warehousing (B5) & {$[20,22,41]$} \\
\hline \multirow{5}{*}{ Green innovation performance $(\mathrm{C})$} & Water conservation $(\mathrm{C} 1)$ & {$[12,29]$} \\
\hline & Level of environmental implications on society (C2) & {$[12,33,42]$} \\
\hline & Level of R\&D expenditure on environmental initiatives (C3) & {$[32,41,43]$} \\
\hline & Carbon emission reduction (C4) & {$[12,29,39]$} \\
\hline & Indoor environment quality (C5) & {$[12,42,43]$} \\
\hline \multirow{5}{*}{$\begin{array}{l}\text { Green innovation monitoring and } \\
\text { follow-up (D) }\end{array}$} & Environmental audits to ensure compliance (D1) & {$[41,43,44]$} \\
\hline & Stringent enforcement of green practices (D2) & {$[41,45,46]$} \\
\hline & Implementation of environmental management system (D3) & {$[10,29,33,47]$} \\
\hline & Incentives for green production (D4) & {$[32,33,43]$} \\
\hline & Technical assistant for technological upgradation (D5) & {$[12,32,43]$} \\
\hline
\end{tabular}

\section{Methodology}

The proposed decision methodology, i.e., Fuzzy AHP and TOPSIS-Grey, is applied to select the most optimum suppliers for SMEs based on suppliers' green innovation ability. The analysis in this study has been carried out for six SMEs operating in Saudi Arabia-names and personal information of SMEs are kept anonymous due to legal issues. The study engaged twelve experts to assign weights to criteria and sub-criteria and score each supplier for each sub-criterion.

The proposed criteria for implementing green innovation activities in SMEs are analyzed using the Fuzzy AHP method. While the TOPSIS-Grey method has been employed to assess and prioritize the significant suppliers for successfully deploying the green innovation practices in SMEs.

\subsection{Fuzzy AHP Method}

Saaty proposed AHP method for multi-criteria decision making in the 1970s [48]. This method has evolved towards more sophisticated variants, such as the Fuzzy AHP presented herein [49-51]. Fuzzy based AHP applies to construct a pairwise matrix of decision-makers' preference using triangular fuzzy numbers (TFNs). The fuzzy scale utilized in this study is given in Table 3.

Table 3. Triangular fuzzy numbers (TFNs) scale.

\begin{tabular}{cc}
\hline Linguistic Preference & TFNs \\
\hline Preferred equally & $(1,1,1)$ \\
Preferred moderately & $(2 / 3,1,3 / 2)$ \\
Preferred strongly & $(3 / 2,2,5 / 2)$ \\
Preferred very-strongly & $(5 / 2,3,7 / 2)$ \\
Preferred extremely & $(7 / 2,4,9 / 2)$ \\
\hline
\end{tabular}


The Fuzzy AHP is applied in the following steps [19]:

- Step 1: Construct a pairwise matrix of attributes using TFNs provided in Table 3.

- Step 2: Define fuzzy synthetic extent value $S Y_{i}$ of $i$ as:

$$
\begin{gathered}
S Y_{i}=\sum_{j=1}^{m} T_{g_{i}}^{j} \times\left[\sum_{i=1}^{n} \sum_{j=1}^{m} T_{g_{i}}^{j}\right]^{-1} \\
\sum_{j=1}^{m} T_{g_{i}}^{j}=\left(\sum_{j=1}^{m} b 1_{i j}, \sum_{j=1}^{m} b 2_{i j}, \sum_{j=1}^{m} b 3_{i j}\right) \\
{\left[\sum_{i=1}^{n} \sum_{j=1}^{m} T_{g_{i}}^{j}\right]^{-1}=\left(\frac{1}{\sum_{n}^{i=1} \sum_{m}^{j=1} b 3_{i j}}, \frac{1}{\sum_{n}^{i=1} \sum_{m}^{j=1} b 2_{i j}}, \frac{1}{\sum_{n}^{i=1} \sum_{m}^{j=1} b 1_{i j}}\right)}
\end{gathered}
$$

- Step 3: Compare the obtained values of $S Y_{i}$ and then calculate the possible degree of $S Y_{j}=$ $\left(b 1_{j}, b 2_{j}, b 3_{j}\right) \geq S Y_{i}=\left(b 1_{i}, b 2_{i}, b 3_{i}\right)$ using the following equation:

$$
V\left(S Y_{j} \geq S Y_{i}\right)=(d)=\left\{\begin{array}{c}
1, \text { in case of } b 2_{j} \geq b 2_{i} \\
0, \text { in case of } b 1_{i} \geq b 3_{j} \\
\frac{b 1_{i}-b 3_{j}}{\left(b 2_{j}-b 3_{j}\right)-\left(b 2_{i}-b 1_{i}\right)}, \text { otherwise }
\end{array}\right\}
$$

where $d$ represents the highest point between $S Y_{j}$ and $S Y_{i}$.

- Step 4: Calculate minimum possibility degree $d(i)$ of $V\left(S Y_{j} \geq S Y_{i}\right)$ for $(i j=1,2,3,4,5, \ldots, k)$ using Equation (3):

$$
\begin{gathered}
V\left(S Y \geq S Y_{1}, S Y_{2}, S Y_{3}, S Y_{4}, S Y_{5} \ldots, S Y_{k}\right) \\
\quad \text { for }(i=1,2,3,4,5 \ldots, k) \\
\quad \text { for }(i=1,2,3,4,5, \ldots, k)
\end{gathered}
$$

Step 5: Let us assume $d^{\prime}\left(A_{i}\right)=\min V\left(S Y \geq S Y_{i}\right)$; for $(i=1,2,3,4,5 \ldots, k)$ then weight vector can be defined as:

$$
W^{\prime}=\left(d^{\prime}\left(A_{1}\right), d^{\prime}\left(A_{2}\right), d^{\prime}\left(A_{3}\right), d^{\prime}\left(A_{4}\right), d\left(A_{5}\right), \ldots, d^{\prime}\left(A_{n}\right)\right)^{T}
$$

Finally, the weight vector can be normalized using Equation (5):

$$
W=\left(d\left(A_{1}\right), d\left(A_{2}\right), d\left(A_{3}\right), d\left(A_{4}\right), d\left(A_{5}\right), \ldots, d\left(A_{n}\right)\right)^{T}
$$

where $W$ represents a non-fuzzy number.

\subsection{TOPSIS}

Ever since Hwang and Yoon proposed the TOPSIS method in 1981, the technique has been commonly used for solving complex decision problems [52]. Few of the recent studies that used TOPSIS include $[50,53]$. The TOPSIS method solves the problem by finding the positive and negative ideal solution. The TOPSIS method is applied in the following seven steps [54]:

- Step 1: Construction of a decision matrix $\mathrm{H}$ which is defined as

$$
[\text { labelsep }=2.8 m m] \mathrm{H}=\left[\begin{array}{ccccc}
x_{11} & x_{12} & \cdots & \cdots & x_{1 m} \\
x_{21} & x_{22} & \cdots & \cdots & x_{2 m} \\
\cdots & \cdots & \cdots & \cdots & \cdots \\
\cdots & \cdots & \cdots & \cdots & \cdots \\
x_{n 1} & x_{n 2} & \cdots & \cdots & x_{n m}
\end{array}\right]
$$


where $\mathrm{H}$ comprises of $n$ alternatives and $m$ criteria; $x_{i j}$ is the evaluation of $i$ th alternative with respect to $j$ th criterion.

- Step 2: Normalization of $\mathrm{H}$ decision matrix as below:

$$
g_{i j}=\frac{x_{i j}}{\sqrt{\sum_{j=1}^{m} x_{i j}^{2}}}(j=1,2, \ldots, m),(i=1,2, \ldots, n)
$$

- Step 3: Develop a weighted matrix from normalized decision matrix using the subsequent equation:

$$
q_{i j}=w_{j} g_{i j},(j=1,2, \ldots, m),(i=1,2, \ldots, n)
$$

where $w_{j}$ represents the criterion weight of $j$ th criterion; the sum of all the criteria equals to 1.

Step 4: Use Equations (9) and (10) to respectively obtain an ideal positive solution $\left(A^{+}\right)$and ideal negative solution $\left(A^{-}\right)$.

$$
\begin{aligned}
& A^{+}=\left\{\left(\max _{i} q_{i j} \mid j \in J\right),\left(\underset{i}{\min q_{i j}} \mid j \in J^{\prime}\right) \mid i \in n\right\}=\left[q_{1}^{+}, q_{2}^{+}, \ldots, q_{m}^{+}\right] z \\
& A^{-}=\left\{\left(\min _{i} q_{i j} \mid j \in J\right),\left(\underset{i}{\max q_{i j}} \mid j \in J^{\prime}\right) \mid i \in n\right\}=\left[q_{1}^{-}, q_{2}^{-}, \ldots, q_{m}^{-}\right]
\end{aligned}
$$

where $J$ represents a benefit-type criterion (the larger value is the better), while, $J^{\prime}$ shows a cost-type criterion (the smaller value is preferred).

Step 5: Once positive ideal and negative ideal solutions are found, then the subsequent step is to find the distance from these points using Euclidean distance [55]. Equation (11) shall be used to find the distance for a benefit-type criterion, while Equation (12) shall find the distance for a cost-type criterion.

$$
\begin{aligned}
d_{i}^{+} & =\left[\sum_{j=1}^{m}\left(q_{i j}-q_{j}^{+}\right)^{2}\right]^{1 / 2},(i=1,2, \ldots, n) \\
d_{i}^{-} & =\left[\sum_{j=1}^{m}\left(q_{i j}-q_{j}^{-}\right)^{2}\right]^{1 / 2},(i=1,2 \ldots, n)
\end{aligned}
$$

Step 6: This step shall use Equation (13) to obtain the relative closeness score $\left(C_{i}^{+}\right)$of the solutions.

$$
C_{i}^{+}=\frac{d_{i}^{-}}{d_{i}^{+}+d_{i}^{-}},(i=1,2, \ldots, n)
$$

Step 7: This is the final step that ranks the alternatives based on relative closeness scores, the better the score the better ranking.

\subsection{Grey System Theory}

The grey system theory was proposed by Professor Deng in 1982 based on the concept of grey set. The theory is proficient in dealing with uncertain and incomplete or insufficient data [56]. The theory uses a grey number to minimize uncertainty in the data. Let us define the grey number as $\otimes \mathrm{X}=[\underline{x}, \bar{x}]$, where $\underline{x}$, and $\bar{x}$ are real numbers, $\underline{x}$ represent the lower limit while $\bar{x}$ denotes the upper limit. In case if values of upper $(\bar{x})$ and lower $(\underline{x})$ limits are known, then it can be called a white number, which means that all the information is known. In case if values of both limits are unknown, then we refer it as a black number, where nothing is known. If any number lies between upper and lower limits, but the value of the number is uncertain, then it is called a grey number. Thus we can represent a grey number as $\underline{x} \leq \otimes \mathrm{X} \leq \bar{x}$. Different mathematical operations on grey numbers can be performed as follows [57]: 


$$
\begin{gathered}
\otimes a+\otimes b=[\underline{a}+\underline{b} ; \bar{a}+\bar{b}] \\
\otimes a-\otimes b=[\underline{a}-\underline{b} ; \bar{a}-\bar{b}] \\
\otimes a \times \otimes b=[\min (\underline{a b}, \quad \overline{a b}, \quad \bar{a} \underline{b}, \quad \underline{a} \bar{b}) ; \max (\underline{a b}, \quad \overline{a b}, \quad \bar{a} \underline{b}, \quad \underline{a} \underline{b})] \\
\otimes a: \otimes b=\otimes a \times\left[\frac{1}{\overline{\bar{b}}}, \frac{1}{\underline{b}}\right] ; 0 \notin \otimes b
\end{gathered}
$$

We can also transform TFNs into grey numbers using $\widetilde{a}=\left(a_{1}, a_{2}, a_{3}\right)$, and $\widetilde{b}=\left(b_{1}, b_{2}, b_{3}\right)$ into grey numbers $\otimes a=\left[a_{1}, a_{2}\right]$, and $\otimes b=\left[b_{1}, b_{2}\right]$ using Euclidean distance between $\otimes a$ and $\otimes b$ as given in the equation below:

$$
d(\otimes a, \otimes b)=\sqrt{\frac{1}{2}\left[(\underline{a}-\underline{b})^{2}+(\bar{a}-\bar{b})^{2}\right]}
$$

\subsection{Fuzzy AHP and TOPSIS-Grey Integrated Methodology}

The proposed methodology uses two widely applied methods of MCDM, which are AHP and TOPSIS. It then integrates AHP with fuzzy set theory and TOPSIS with grey set theory to form Fuzzy AHP and TOPSIS-Grey, respectively. Initially, the methodology applies Fuzzy AHP, which draws the hierarchal structure of the problem and find weights of criteria and sub-criteria [58]. Later, TOSIS-Grey is utilized to prioritize the alternatives based on the criteria and sub-criteria weights. The schematic of the methodological proceeding is given in Figure 1. 


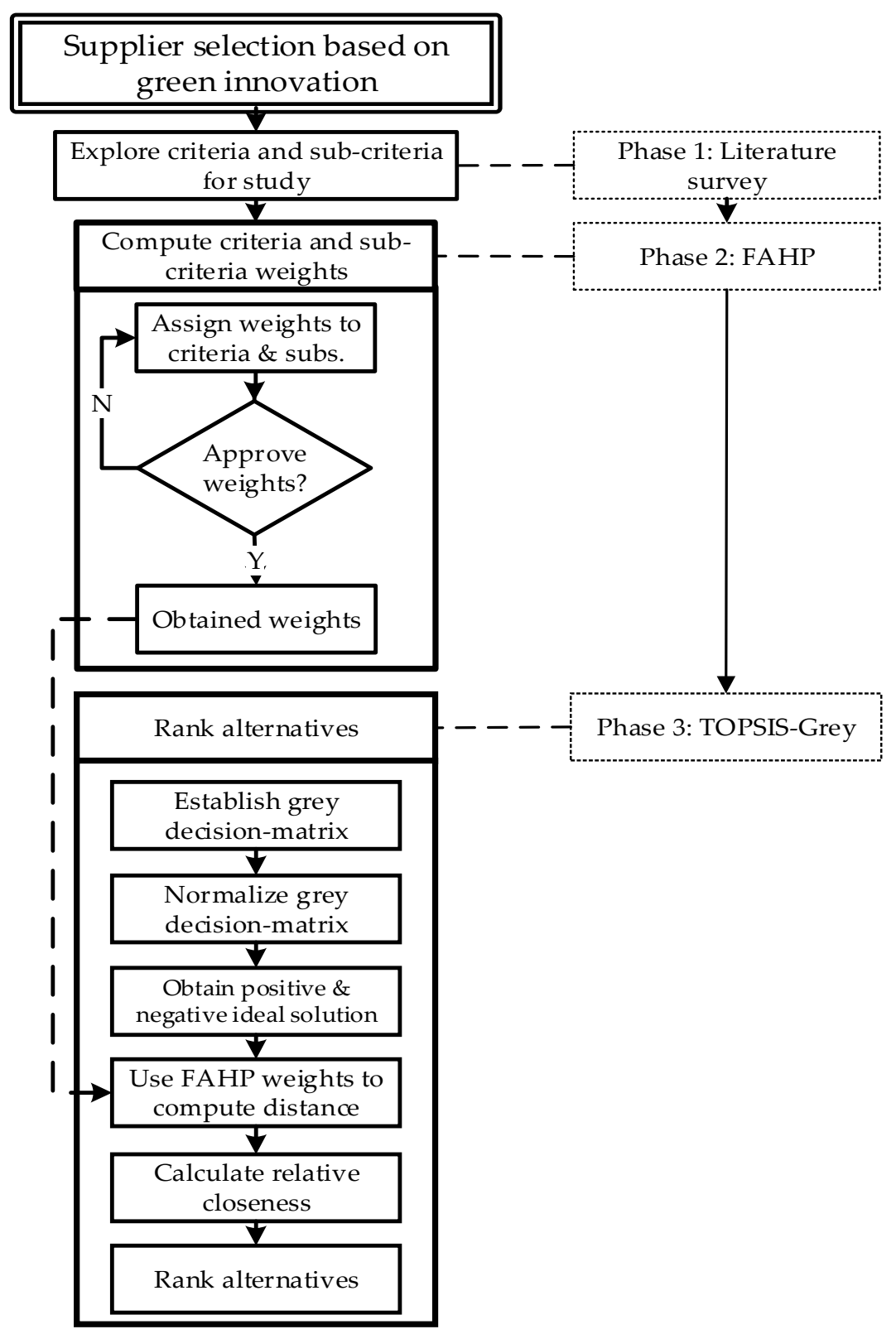

Figure 1. Model representation.

The integrated methodology involves the following steps:

- Step 1: Establish the structure of the problem by defining the goal to be achieved, criteria, and sub-criteria used for evaluation, and alternatives which are to be evaluated.

- Step 2: Involve experts to provide their judgment regarding the criteria and sub-criteria and then apply Fuzzy AHP to obtain weights of criteria and sub-criteria.

- Step 3: Use linguistics values given in Table 4 to rate the alternatives with respect to each sub-criterion.

- Step 4: Define the decision matrix of TOPSIS-Grey $H^{l}$ as:

$$
\mathrm{H}^{l}=\left[\begin{array}{cccc}
\otimes x_{11}^{l} & \otimes x_{12}^{l} & \ldots & \otimes x_{1 m}^{l} \\
\otimes x_{21}^{l} & \otimes x_{22}^{l} & \ldots & \otimes x_{2 m}^{l} \\
\ldots & \ldots & \ldots & \ldots \\
\otimes x_{n 1}^{l} & \otimes x_{n 2}^{l} & \ldots & \otimes x_{n m}^{l}
\end{array}\right]
$$


where $\otimes x_{\mathrm{ij}}^{l}$ shows the grey evaluation of $i$ th alternative for $j$ th criterion by decision-maker $l$ $(l=1,2,3, \ldots, l) ; \otimes x_{i}^{l}=\left[\otimes x_{i 1}^{l}, \otimes x_{i 2}^{l}, \otimes x_{i 3^{\prime}}^{l}, \ldots, \otimes x_{i m}^{l}\right]$ depicts $k$ th decision-maker's evaluation for ith alternative.

Step 5: Normalize $\mathrm{H}^{d}$ using Equation (20) (benefit-type criterion) and Equation (21) (cost-type criterion):

$$
\begin{gathered}
\otimes g_{i j}=\left[\left(\frac{\otimes x_{i j}}{\max _{i}\left(\bar{x}_{i j}\right)}\right)=\left(\frac{\underline{x}_{i j}}{\max _{i}\left(\bar{x}_{i j}\right)} ; \frac{\bar{x}_{i j}}{\max _{i}\left(\bar{x}_{i j}\right)}\right)\right] \\
\otimes g_{i j}=\left[\left(1-\frac{\otimes x_{i j}}{\max _{i}\left(\bar{x}_{i j}\right)}\right)=\left(1-\frac{\bar{x}_{i j}}{\max _{i}\left(\bar{x}_{i j}\right)} ; 1-\frac{\underline{x}_{i j}}{\max _{i}\left(\bar{x}_{i j}\right)}\right)\right]
\end{gathered}
$$

where $\underline{x}_{i j}$ is the lower value of the interval and $\bar{x}_{i j}$ is the upper value of the interval.

Step 6: Use Equations (22) and (23) respectively to find out positive ideal alternative $\left(A_{i}^{d+}\right)$ and negative ideal alternative $\left(A_{i}^{d-}\right)$ as below:

$$
\begin{aligned}
& A_{i}^{l+}=\left\{\left(\max _{i} \bar{g}_{i j} \mid j \in J\right),\left(\min _{i} \underline{g}_{i j} \mid j \in J^{\prime}\right) \mid i \in n\right\}=\left[l_{1}^{+}, l_{2}^{+}, \ldots, l_{m}^{+}\right] \\
& A_{i}^{l-}=\left\{\left(\min _{i} \underline{g}_{i j} \mid j \in J\right),\left(\underset{\max }{\max _{i j} \mid} \mid j \in J^{\prime}\right) \mid i \in n\right\}=\left[l_{1}^{-}, l_{2}^{-}, \ldots, l_{m}^{-}\right]
\end{aligned}
$$

where $J$ is a benefit-type criterion whose larger value is preferred while $J^{\prime}$ is a cost-type criterion whose smaller value is better.

Step 7: Compute the positive ideal solution $\left(d_{i}^{l+}\right)$ and negative ideal solution $\left(d_{i}^{l-}\right)$ using Equations (24) and (25), respectively as below:

$$
\begin{aligned}
& d_{i}^{l+}=\left\{\frac{1}{2} \sum w_{j}\left[\left|g_{j}^{l+}-\underline{g}_{i j}^{l}\right|^{p}+\left|g_{j}^{l+}-\bar{g}_{i j}^{l}\right|^{p}\right]\right\}^{1 / p} \\
& d_{i}^{l-}=\left\{\frac{1}{2} \sum w_{j}\left[\left|g_{j}^{l-}-\underline{g}_{i j}^{l}\right|^{p}+\left|g_{j}^{l-}-\bar{g}_{i j}^{l}\right|^{p}\right]\right\}^{1 / p}
\end{aligned}
$$

Step 8: Use Equation (26) to compute the relative closeness score $\left(C_{i}^{l+}\right)$ as follows:

$$
C_{i}^{l+}=\frac{d_{i}^{l-}}{d_{i}^{l+}+d_{i}^{l-}},(i=1,2,3, \ldots, n)
$$

Step 9: Based on $C_{i}^{l+}$ score, rank the alternatives; the higher the $C_{i}^{l+}$ score the higher the ranking.

Table 4. Greyscale adopted for rating alternatives.

\begin{tabular}{cc}
\hline Linguistic & $\otimes \mathbf{X}$ \\
\hline Very-low (VL) & {$[0,1]$} \\
Low (L) & {$[1,3]$} \\
Moderate-low (ML) & {$[3,4]$} \\
Moderate (M) & {$[4,5]$} \\
Moderate-high (MH) & {$[5,6]$} \\
High (H) & {$[6,9]$} \\
Very-high (VH) & {$[9,10]$} \\
\hline
\end{tabular}




\section{Results and Analysis}

The results are presented in two parts. Firstly, Fuzzy AHP results are given, which provide weights of main criteria and sub-criteria. The latter part presents TOPSIS-Grey results, which rank suppliers based on sub-criteria weights computed in the first part.

\subsection{Fuzzy AHP Results}

\subsubsection{Hierarchical Structure}

The first and foremost step of Fuzzy AHP is to transform the supplier selection problem into a hierarchical structure. Figure 2 sketches the hierarchal structure of the study. It can be seen that the structure of the problem is divided into four levels, such as goal, criteria, sub-criteria, and alternatives. After drawing the sketch, weights of criteria and sub-criteria are computed and presented in subsequent sections.

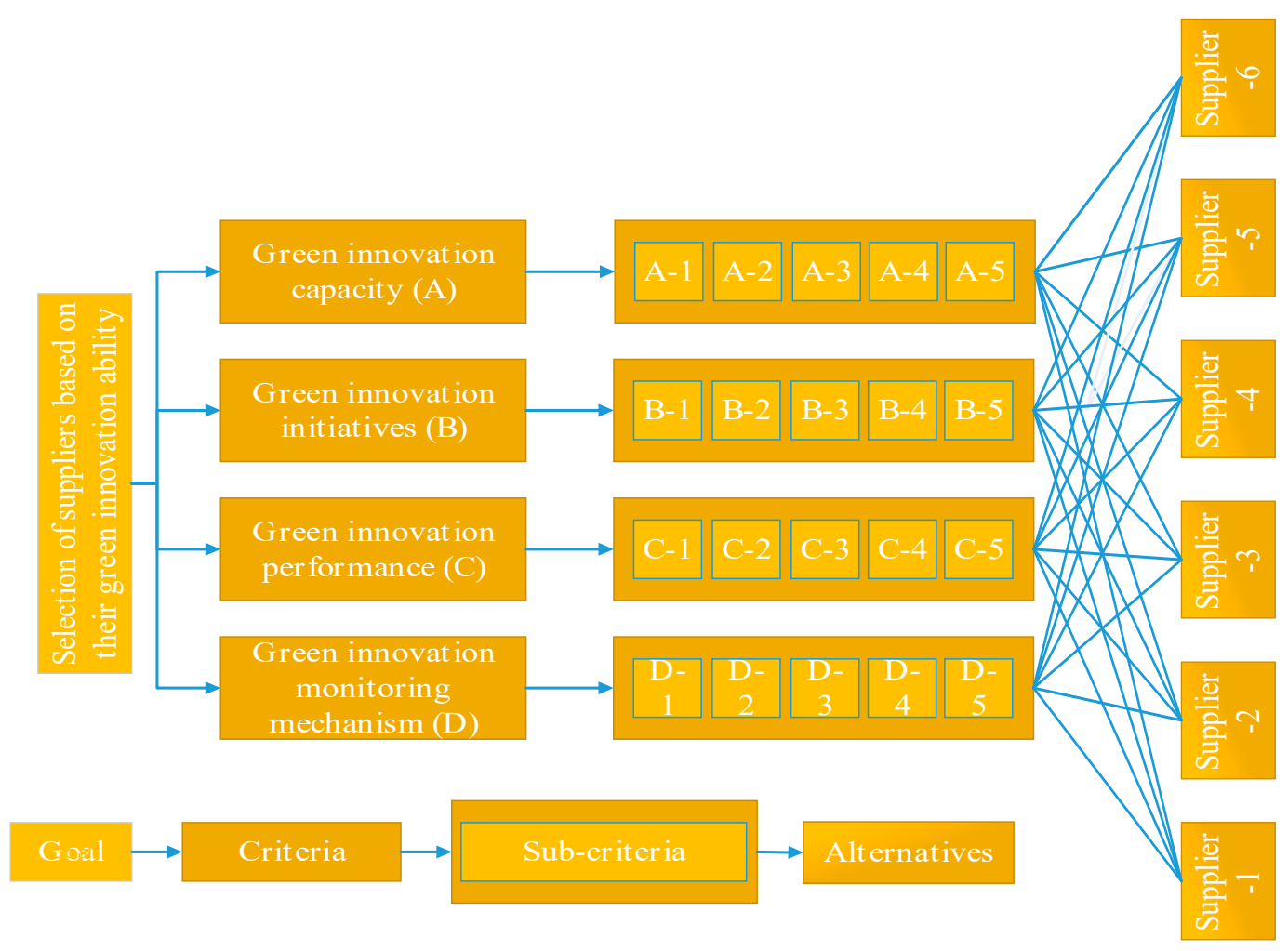

Figure 2. The hierarchal structure of supplier selection.

\subsubsection{Main Criteria Weights}

After giving the hierarchal structure of the problem, the Fuzzy AHP calculates the weights of four main criteria, i.e., Green innovation capacity (A), Green innovation initiatives (B), Green innovation performance $(C)$, and Green innovation monitoring mechanism (D). Table 5 provides a pairwise matrix of main criteria, while the weights of the main criteria are shown in Figure 3. The results show that the "Green innovation initiatives (A)" achieved the highest weight of 0.256 . The "Green innovation monitoring mechanism" attained the second-highest weight of 0.252 . The criterion "Green innovation performance" reported obtaining the third highest weight of 0.248 . The "Green innovation capacity" criterion achieved the lowest weight of 0.244 . The important point to be mentioned here is that the difference between the weights of top-ranked and bottom-ranked criteria is only $4 \%$, which is not substantial. Thus it can be said that all the criteria are significant for suppliers' evaluation. 
Table 5. Pairwise matrix of main criteria.

\begin{tabular}{ccccc}
\hline & $\begin{array}{c}\text { Green Innovation } \\
\text { Capacity (A) }\end{array}$ & $\begin{array}{c}\text { Green Innovation } \\
\text { Initiatives (B) }\end{array}$ & $\begin{array}{c}\text { Green Innovation } \\
\text { Performance (C) }\end{array}$ & $\begin{array}{c}\text { Green Innovation } \\
\text { Monitoring } \\
\text { Mechanism (D) }\end{array}$ \\
\hline Green innovation capacity (A) & $1,1,1$ & $0.587,0.825,1.193$ & $0.81,1.134,1.593$ & $0.728,1,1.373$ \\
\hline Green innovation initiatives (B) & $0.838,1.212,1.704$ & $1,1,1$ & $0.541,0.724,1$ & $0.874,1.23,1.704$ \\
\hline Green innovation performance (C) & $0.628,0.882,1.234$ & $1,1.381,1.847$ & $1,1,1$ & $0.601,0.779,1.019$ \\
\hline $\begin{array}{c}\text { Green innovation monitoring } \\
\text { mechanism (D) }\end{array}$ & $0.728,1,1.373$ & $0.587,0.813,1.144$ & $0.982,1.284,1.664$ & $1,1,1$ \\
\hline \multicolumn{2}{c}{$\mathrm{CR}=0.0274$} \\
\hline \multicolumn{5}{c}{}
\end{tabular}

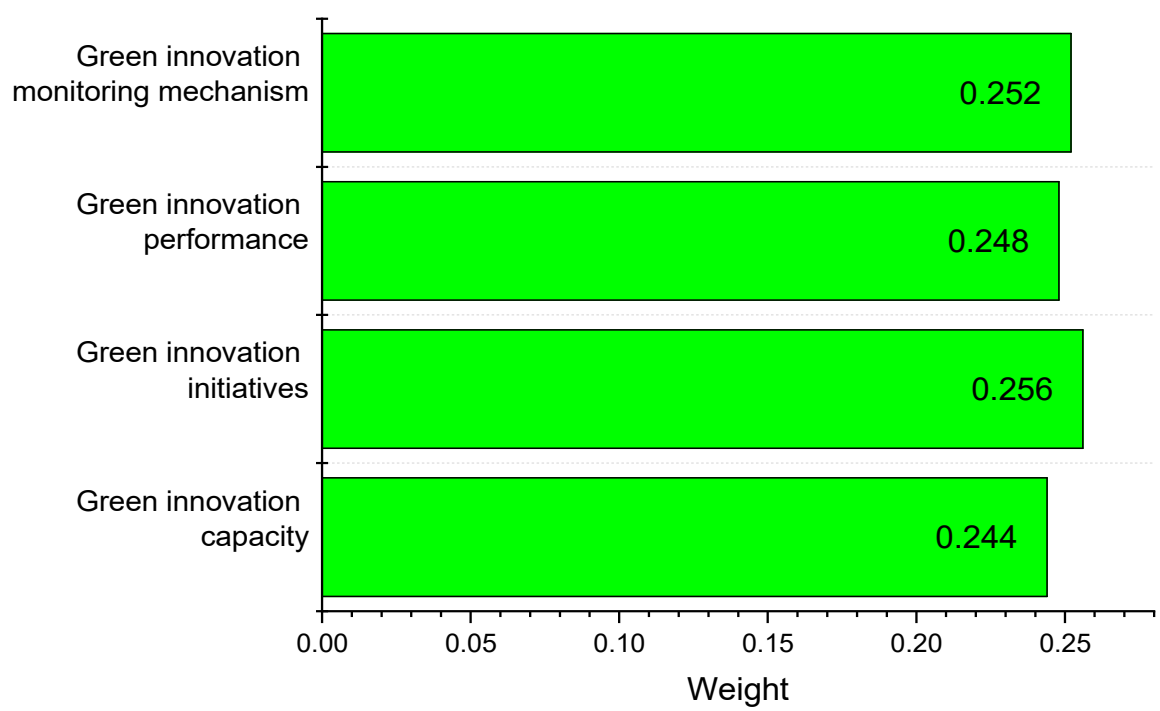

Figure 3. Main criteria final weights.

\subsubsection{Sub-Criteria Initial Weights}

After obtaining weights of main criteria, similar steps of Fuzzy AHP were applied to calculate sub-criteria weights with respect to their respective criterion. Alike constructing the main criteria pairwise matrix, four pairwise matrices were constructed (one pairwise matrix for each criterion), which are given in tables provided in Appendix A Tables A1-A4.

Figure 4 shows sub-criteria weights with respect to the 'Green Innovation Capacity (A)' criterion. Under this criterion, Supplier's economic competitiveness (A-2) sub-criterion received the highest weight of $21.1 \%$ followed respectively by Capacity of supplier's general innovation (A-2) $20.7 \%$, Awareness about sustainability management (A-3) 20.5\%, Production efficiency (A-5) $19.4 \%$, and Trained human resources (A-4) $18.3 \%$.

Figure 5 presents sub-criteria weights with respect to the "Green Innovation Initiatives (B)" criterion. It shows that Share of renewable energy utilization (B-1) criterion obtained highest weight of $22.2 \%$ followed respectively by Energy efficiency and conservation (B-2) 20.5\%, Green recycling (B-4) $20.0 \%$, and Green transportation (B-3) 19.6\%. The sub-criterion Green warehousing (B-5) received the least weight of $17.7 \%$ under the Green Innovation Initiatives criterion.

Figure 6 depicts the weights of sub-criteria under the "Green Innovation Performance (C)" criterion. It can be seen that the sub-criterion Level of environmental implications on society (C-2) received the highest weight of $21.2 \%$. The sub-criterion Carbon emission reduction (C-4) got the second-highest weight of $20.8 \%$. The level of R\&D expenditure on environmental initiatives (C-3) obtained the third highest weight of $20.5 \%$. Water conservation (C-1) and Indoor environment quality (C-5) received second-lowest and lowest weights of $19.7 \%$ and $17.8 \%$, respectively. 


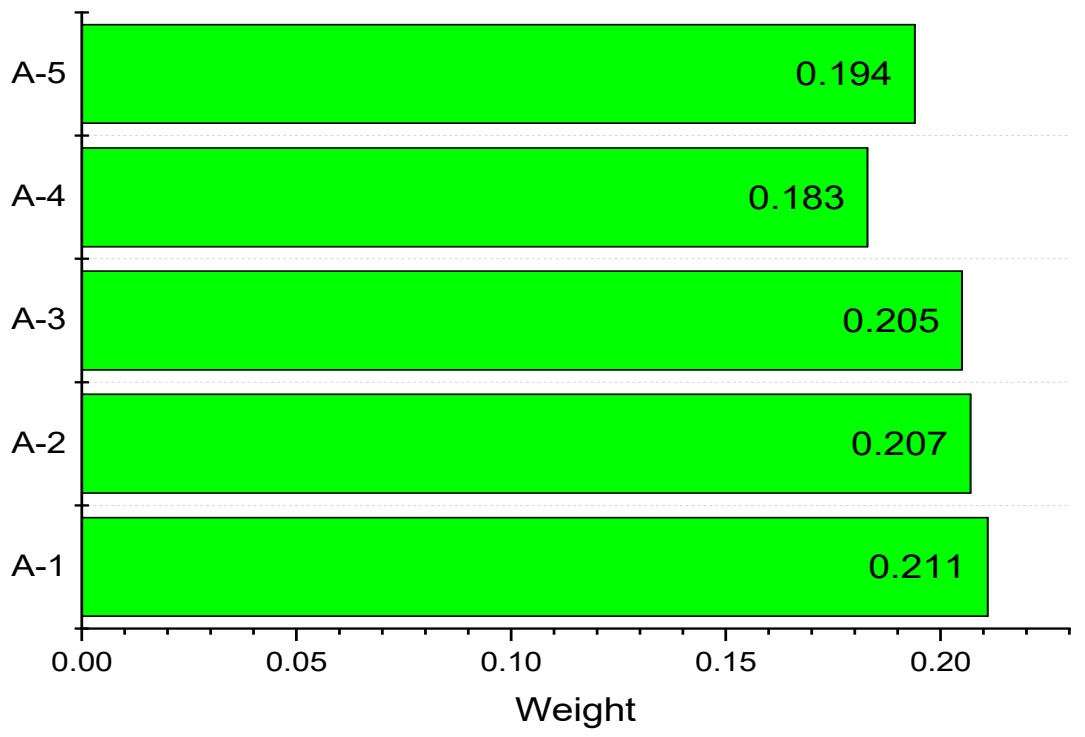

Figure 4. Initial weights of sub-criteria under Green Innovation Capacity.

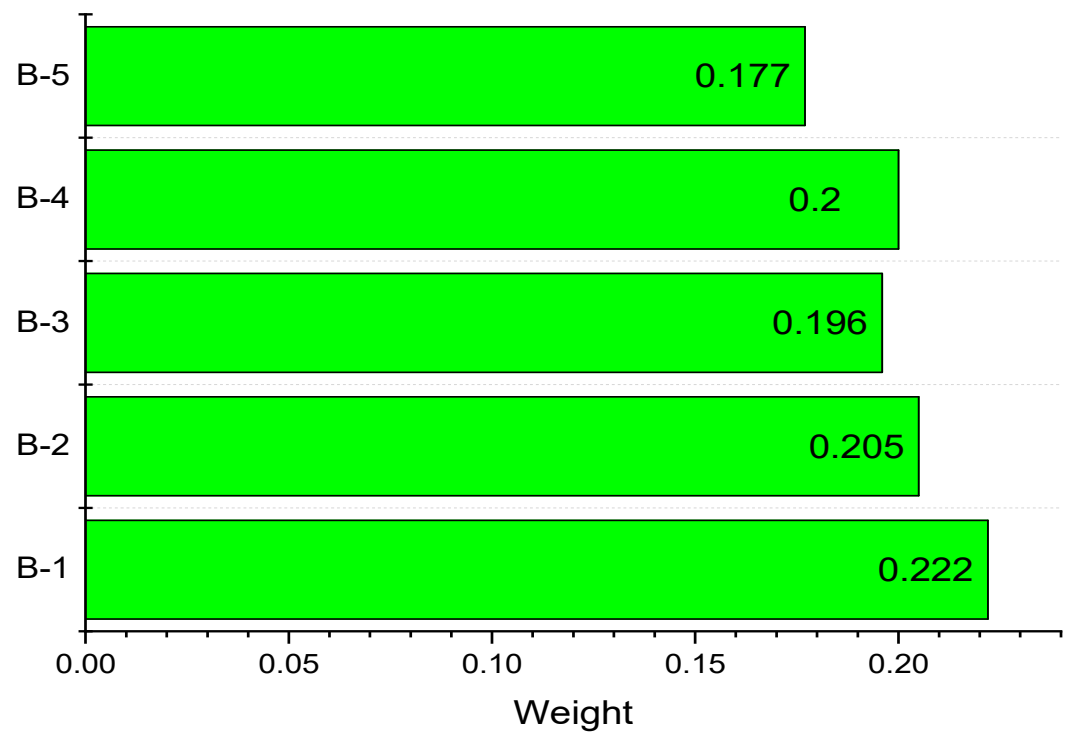

Figure 5. Initial weights of sub-criteria under Green Innovation Initiatives.

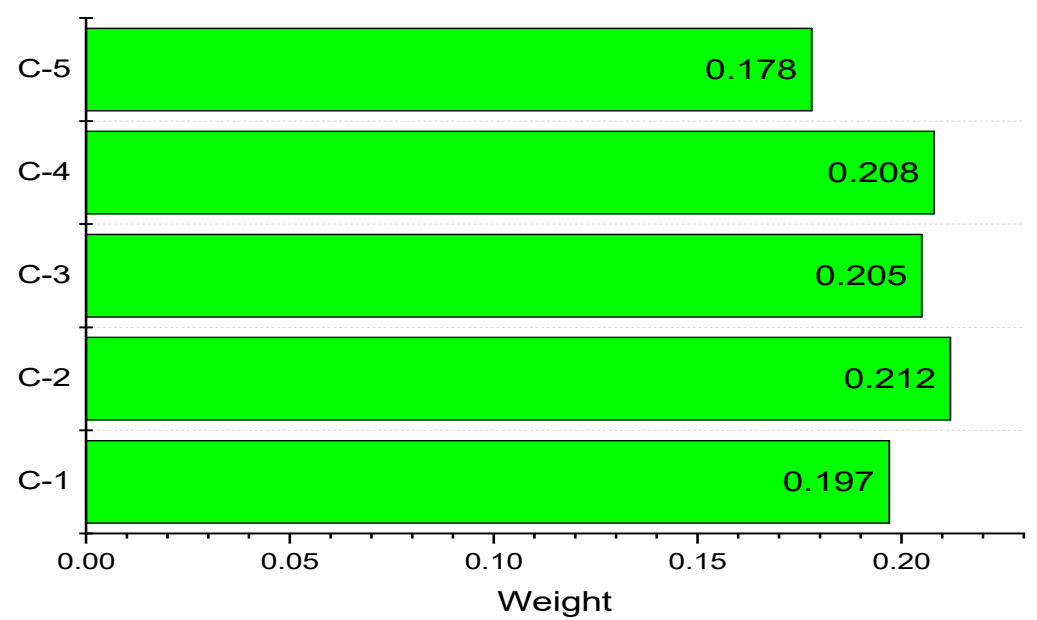

Figure 6. Initial weights of sub-criteria under Green Innovation Performance. 
Figure 7 displays sub-criteria weights with respect to the "Green Innovation Monitoring Mechanism (D)" criterion. The Stringent enforcement of green practices (D-2) sub-criterion reported achieving $21.1 \%$ of weight, which is the highest weight obtained under the Stringent enforcement of green practices criterion. Environmental audits to ensure compliance (D-1) and Implementation of the environmental management system (D-3) received second and third highest weights of $20.9 \%$ and $20.8 \%$, respectively. Incentives for green production (D-4) got the second-lowest weight of $20.2 \%$ while Technical assistant for technological up-gradation (D-5) obtained the lowest weight of $17.0 \%$.

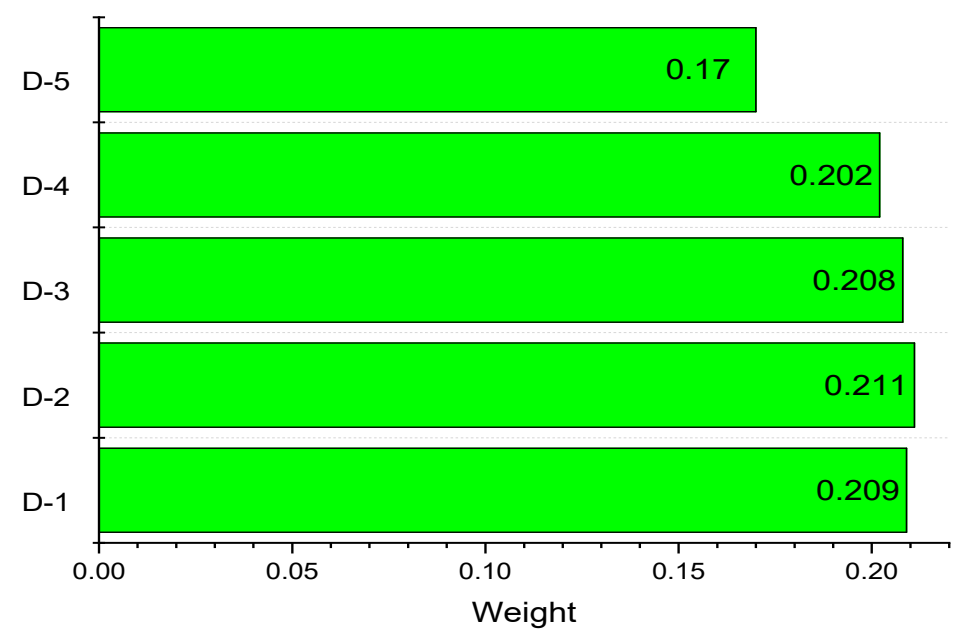

Figure 7. Initial weights of sub-criteria under Green Innovation Monitoring Mechanism.

\subsubsection{Final Weights of Sub-Criteria}

After computing weights of main criteria and sub-criteria, we calculated sub-criteria final weights by multiplying the initial weights of sub-criteria to their respective main criterion. The obtained final weights shall be used in TOPSIS-Grey for alternatives' ranking. We list the final weights of sub-criteria in Table 6. It can be seen that the sub-criterion "Share of renewable energy utilization (B-1)" topped among all the twenty sub-criteria. The B-1 sub-criterion belongs to the main criteria "Green Innovation Initiatives", which also topped among the four main criteria. The B-1 sub-criterion received the highest final weight of 0.057. In contrast, sub-criterion "Technical assistant for technological up-gradation (D-5)" got the least final weight of 0.043 and subsequently ranked last in the row. The D-5 is the sub-criterion of the main criterion "Green innovation monitoring mechanism," which achieved the second-highest weight among four main criteria. Among twenty sub-criteria, final weights of 14 sub-criteria remained greater than or equal to 0.050 , while only 6 sub-criteria achieved final weights less than 0.050 .

Table 6. Final weights of overall green innovation criteria.

\begin{tabular}{ccccccc}
\hline \multirow{2}{*}{ Criteria } & $\begin{array}{c}\text { Main Criteria } \\
\text { Weight }\end{array}$ & Sub-Criteria & Code & $\begin{array}{c}\text { Sub-Criteria } \\
\text { Weight }\end{array}$ & $\begin{array}{c}\text { Global } \\
\text { Weight }\end{array}$ & Rank \\
\hline \multirow{2}{*}{$\begin{array}{c}\text { Green innovation } \\
\text { capacity (A) }\end{array}$} & 0.244 & $\begin{array}{c}\text { Supplier's economic } \\
\text { competitiveness }\end{array}$ & A-1 & 0.211 & 0.051 & 8 \\
\cline { 3 - 7 } & & $\begin{array}{c}\text { Capacity of supplier's } \\
\text { general innovation }\end{array}$ & A-2 & 0.207 & 0.051 & 12 \\
\cline { 2 - 7 } & & $\begin{array}{c}\text { Awareness about } \\
\text { sustainability management }\end{array}$ & A-3 & 0.205 & 0.050 & 14 \\
\cline { 2 - 7 } & Trained human resources & A-4 & 0.183 & 0.045 & 18 \\
\cline { 2 - 7 } & Production efficiency & A-5 & 0.194 & 0.047 & 16 \\
\hline
\end{tabular}


Table 6. Cont.

\begin{tabular}{|c|c|c|c|c|c|c|}
\hline Criteria & $\begin{array}{l}\text { Main Criteria } \\
\text { Weight }\end{array}$ & Sub-Criteria & Code & $\begin{array}{l}\text { Sub-Criteria } \\
\text { Weight }\end{array}$ & $\begin{array}{l}\text { Global } \\
\text { Weight }\end{array}$ & Rank \\
\hline \multirow{5}{*}{$\begin{array}{l}\text { Green innovation } \\
\text { initiatives (B) }\end{array}$} & \multirow{5}{*}{0.256} & $\begin{array}{c}\text { Share of renewable energy } \\
\text { utilization }\end{array}$ & B-1 & 0.222 & 0.057 & 1 \\
\hline & & $\begin{array}{c}\text { Energy efficiency and } \\
\text { conservation }\end{array}$ & B-2 & 0.205 & 0.052 & 5 \\
\hline & & Green transportation & B-3 & 0.196 & 0.050 & 13 \\
\hline & & Green recycling & B-4 & 0.200 & 0.051 & 9 \\
\hline & & Green warehousing & B-5 & 0.177 & 0.045 & 17 \\
\hline \multirow{5}{*}{$\begin{array}{l}\text { Green innovation } \\
\text { performance }(C)\end{array}$} & \multirow{5}{*}{0.248} & Water conservation & $C-1$ & 0.197 & 0.049 & 15 \\
\hline & & $\begin{array}{l}\text { Level of environmental } \\
\text { implications on society }\end{array}$ & $C-2$ & 0.212 & 0.053 & 4 \\
\hline & & $\begin{array}{c}\text { Level of R\&D expenditure } \\
\text { on environmental } \\
\text { initiatives }\end{array}$ & C-3 & 0.205 & 0.051 & 11 \\
\hline & & Carbon emission reduction & C-4 & 0.208 & 0.052 & 7 \\
\hline & & Indoor environment quality & C-5 & 0.178 & 0.044 & 19 \\
\hline \multirow{5}{*}{$\begin{array}{l}\text { Green innovation } \\
\text { monitoring } \\
\text { mechanism (D) }\end{array}$} & \multirow{5}{*}{0.252} & $\begin{array}{l}\text { Environmental audits to } \\
\text { ensure compliance }\end{array}$ & D-1 & 0.209 & 0.053 & 3 \\
\hline & & $\begin{array}{l}\text { Stringent enforcement of } \\
\text { green practices }\end{array}$ & D-2 & 0.211 & 0.053 & 2 \\
\hline & & $\begin{array}{l}\text { Implementation of } \\
\text { environmental } \\
\text { management system }\end{array}$ & D-3 & 0.208 & 0.052 & 6 \\
\hline & & $\begin{array}{l}\text { Incentives for green } \\
\text { production }\end{array}$ & D-4 & 0.202 & 0.051 & 10 \\
\hline & & $\begin{array}{l}\text { Technical assistant for } \\
\text { technological upgradation }\end{array}$ & D-5 & 0.170 & 0.043 & 20 \\
\hline
\end{tabular}

\subsubsection{Ranking of Alternatives Using TOPSIS-Grey}

The developed TOPSIS-Grey integrated methodology has been used to assess and prioritize the six suppliers. The ranking was computed based on four main criteria and twenty sub-criteria. During the phase of applying TOPSIS-Grey, the experts were requested to rate each alternative (supplier) individually with respect to all the twenty sub-criteria. To compute ratings given by the experts, we initially developed a grey decision matrix and later normalized that matrix for further process. The grey decision matrix, grey normalized decision matrix, positive and negative ideal solutions, and positive and the distance from the negative ideal solution are presented in Appendix B (Tables A5-A9). The final step involved in the TOPSIS-Grey integrated methodology was to compute alternatives' relative closeness and obtain final rankings according to the relative closeness scores (bigger the better). The relative closeness scores and the subsequent rankings of all the six suppliers are given in Table 7. The "Supplier-3" achieved the highest relative closeness of 0.579, which means that the Supplier-3 has the highest green innovation ability among the evaluated suppliers. Supplier-2 received the second-highest score of 0.57 . The difference between the relative closeness scores of Supplier-3 and Supplier-1 is not much; hence it can be said that both suppliers can be considered for their green innovation ability. However, the Supplier-3 must be the top priority. Supplier- 6 ranked third by achieving the third-highest relative closeness score of 0.528 . Supplier- 2 ranked fourth by securing a 0.511 relative closeness score. Supplier-4 ranked fifth (0.419) while Supplier-5 bottomed the list by obtaining the least relative closeness score of 0.375 . 
Table 7. The final ranking of suppliers based on green innovation activities in small and medium enterprises (SMEs).

\begin{tabular}{lcccc}
\hline & $\boldsymbol{d}_{\boldsymbol{i}}^{k+}$ & $\boldsymbol{d}_{\boldsymbol{i}}^{k-}$ & $\mathbf{C}+$ & Ranking \\
\hline Supplier-1 & 0.227 & 0.301 & 0.57 & 2 \\
Supplier-2 & 0.257 & 0.269 & 0.511 & 4 \\
Supplier-3 & 0.226 & 0.311 & 0.579 & 1 \\
Supplier-4 & 0.307 & 0.221 & 0.419 & 5 \\
Supplier-5 & 0.333 & 0.2 & 0.375 & 6 \\
Supplier-6 & 0.259 & 0.29 & 0.528 & 3 \\
\hline
\end{tabular}

\subsection{Discussion}

Before conducting this study, it was ambiguous which criteria and sub-criteria are vital for the selection of green suppliers for SMEs. However, this study made it possible for decision-makers to analyze and prioritize the essential criteria and sub-criteria for the selection of suppliers in terms of implementing green practices in SMEs. It was done based on integrated Fuzzy AHP and TOPSIS-Grey methodology. The study also conducted a comprehensive set of literature to identify important criteria which are useful for the selection of green supplier in SMEs. The assessment process in daily life is crucial, difficult, and contains fuzziness. Therefore, this research uses a systematic decision framework for the evaluation of suppliers in terms of green innovation ability. The proposed decision framework can help in handling and removing the shortcomings and uncertainties during decision making.

Rankings of main-criteria and sub-criteria obtained are presented in Figures 2-6. The global weights of sub-criteria are presented in Table 3. Among four main-criteria, i.e., green innovation initiatives, green innovation monitoring mechanisms, green innovation performance, and green innovation capacity, green innovation initiatives criterion is ranked as most important in the selection of suppliers for transforming green SMEs. From the final rankings of sub-criteria, the share of renewable energy utilization (B-1) is considered as the most significant sub-criteria, followed by stringent enforcement of green practices (D-2), and environmental audits to ensure compliance (D-1) which are ranked second and third important sub-criteria. Furthermore, the other remaining sub-criteria rank as: C-2 $>$ B-2 $>$ D-3 $>$ C-4 $>$ A-1 $>$ B-4 $>$ D-4 $>$ C-3 $>$ A-2 $>$ B-3 $>$ A-3 $>$ C-1 $>$ A-5 $>$ B-5 $>$ A-4 $>$ C-5 $>$ D-5. After identifying the main-criteria and sub-criteria results using the Fuzzy AHP method, this study further utilizes the TOPSIS-Grey method to evaluate and rank six suppliers based on Fuzzy AHP results. The TOPSIS-Grey method indicates that supplier-3 is the most significant supplier for the transformation of SMEs into green SCM operations.

In the existing literature, we found a lack of any comprehensive study conducted for SME's in the context of Saudi Arabia. However, studies for other regions were found which analyzed feasible suppliers for green SCM practices. In most cases, the authors used different MCDM methods to assess the decision problem, such as the AHP method was used to identify the sustainable supplier for implementing the green supply practices in the organization $[20,24]$. Other such examples include TOPSIS [34,59], VIKOR [20,22], DEA [37,38,60], ANP [23,44], and DEMATEL [25,61]. However, the current decision problem $\mathrm{f}$ supplier selection based on green innovation ability is even more crucial. Thus, this study utilizes Fuzzy AHP and TOPSIS-Grey methodology to determine the decision problem. This research is beneficial and unique in terms of analyzing and ranking of green suppliers for SMEs. In this study, it is shown that the ranking of main-criteria, sub-criteria, and suppliers is a complex and challenging task, which requires a proficient method for solution. The proposed integrated framework is a handy and supporting decision tool for policymakers in determining the suppliers for transforming the firm's innovation activities in green SCM. 


\section{Conclusions}

Nowadays, organizations are playing a pivotal role in the integration of sustainable environmental management activities into SCM practices. Therefore, the strict policy regulations from governments, environmental agencies, and pressure from other social groups force firms to implement a sustainable production process. Subsequently, companies are exploring new ways to reduce adverse environmental impacts. Recently, green innovation activities have emerged to be vital for SMEs incorporating green supply chain activities. However, the coordination and cooperation with business partners for green supply chain practices remain challenging because SMEs are resource-constrained and unwilling to accept changes required for green initiatives. Therefore, it is crucial to select feasible suppliers who are already implementing green innovation activities in their routine operations.

This study proposed Fuzzy AHP and TOPSIS-Grey methodology to assess optimum suppliers for SMEs based on green innovation criteria. The proposed decision methodology of this study is best suited for companies selecting suppliers for incorporating firms' activities into green SCM practices. The Fuzzy AHP method was used to assess and rank four critical criteria and twenty sub-criteria, and the TOPSIS-Grey method was implemented to evaluate and prioritize the suppliers by utilizing the criteria weights obtained by Fuzzy AHP method. The results of Fuzzy AHP indicate that the 'green innovation initiatives' criterion is the most critical criterion in supplier selection, which transforms the firm's activities into green SCM. The TOPSIS-Grey results reveal that Supplier-3 is the preferred supplier among all the six suppliers under study.

\section{Limitations and Future Research Directions}

This research has some limitations which can be overcome in future research. First of all, this study utilizes a Fuzzy AHP and TOPSIS-Grey methodology for the selection of suppliers based on their green innovation ability, but other MCDM methods such as ELECTRE, ANP, DEA, DEMATEL, and VIKOR can also be undertaken for a future research study. Secondly, the sensitivity analysis can be done by varying the weights of each criterion and sub-criteria to analyze the robustness of the obtained results. Further, in this study, the case has been taken for one sector; however, analysis can be extended to other levels as well given the large sample size and availability of the dataset.

Author Contributions: All the authors contributed to this work. A.S.M.O. and Z.Z. conceived and structured the study. S.A.A.S. undertook the survey and along with Z.A.S., A.S.M.O., and G.M.S. developed the methodology and preliminary manuscript. Y.A.S. and A.O.M.O. reviewed and improved the manuscript. All authors have read and agreed to the published version of the manuscript.

Funding: This research received no external funding.

Conflicts of Interest: The authors declare no conflict of interest.

\section{Appendix A}

Table A1. Pairwise matrix of sub-criteria with respect to Green Innovation Capacity.

\begin{tabular}{cccccc}
\hline & A-1 & A-2 & A-3 & A-4 & A-5 \\
\hline A-1 & $1,1,1$ & $0.771,1.096,1.541$ & $0.739,1.019,1.407$ & $0.779,1.122,1.609$ & $0.742,1.122,1.689$ \\
A-2 & $0.649,0.913,1.296$ & $1,1,1$ & $0.798,1.161,1.633$ & $0.687,1.034,1.579$ & $0.742,1.122,1.689$ \\
A-3 & $0.711,0.982,1.353$ & $0.612,0.861,1.253$ & $1,1,1$ & $0.926,1.303,1.763$ & $0.687,1.015,1.455$ \\
A-4 & $0.622,0.891,1.284$ & $0.633,0.967,1.455$ & $0.567,0.767,1.079$ & $1,1,1$ & $0.649,0.926,1.296$ \\
A-5 & $0.592,0.891,1.348$ & $0.592,0.891,1.348$ & $0.687,0.985,1.455$ & $0.771,1.079,1.541$ & $1,1,1$ \\
\hline \multicolumn{7}{c}{ CR $=0.0028$} \\
\hline
\end{tabular}


Table A2. Pairwise matrix of sub-criteria with respect to Green Innovation Initiatives.

\begin{tabular}{cccccc}
\hline & B-1 & B-2 & B-3 & B-4 & B-5 \\
\hline B-1 & $1,1,1$ & $0.771,1.161,1.689$ & $0.687,1,1.455$ & $0.926,1.284,1.763$ & $0.802,1.172,1.673$ \\
B-2 & $0.592,0.861,1.296$ & $1,1,1$ & $0.786,1.106,1.594$ & $0.671,0.899,1.253$ & $0.913,1.284,1.79$ \\
B-3 & $0.687,1,1.455$ & $0.627,0.905,1.272$ & $1,1,1$ & $0.675,0.976,1.407$ & $0.798,1.043,1.373$ \\
B-4 & $0.567,0.779,1.079$ & $0.798,1.113,1.49$ & $0.711,1.024,1.482$ & $1,1,1$ & $0.798,1.122,1.505$ \\
B-5 & $0.598,0.853,1.246$ & $0.559,0.779,1.096$ & $0.728,0.958,1.253$ & $0.664,0.891,1.253$ & $1,1,1$ \\
\hline \multicolumn{7}{c}{ CR $=0.0037$} \\
\hline
\end{tabular}

Table A3. Pairwise matrix of sub-criteria with respect to Green Innovation Performance.

\begin{tabular}{cccccc}
\hline & C-1 & C-2 & C-3 & C-4 & C-5 \\
\hline C-1 & $1,1,1$ & $0.753,1,1.328$ & $0.592,0.813,1.183$ & $0.622,0.874,1.234$ & $0.896,1.272,1.73$ \\
C-2 & $0.753,1,1.328$ & $1,1,1$ & $0.786,1.106,1.594$ & $0.728,1,1.373$ & $0.861,1.241,1.747$ \\
C-3 & $0.845,1.23,1.689$ & $0.627,0.905,1.272$ & $1,1,1$ & $0.675,0.976,1.407$ & $0.798,1.043,1.373$ \\
C-4 & $0.81,1.144,1.609$ & $0.728,1,1.373$ & $0.711,1.024,1.482$ & $1,1,1$ & $0.728,1.059,1.505$ \\
C-5 & $0.578,0.786,1.116$ & $0.572,0.806,1.161$ & $0.728,0.958,1.253$ & $0.664,0.944,1.373$ & $1,1,1$ \\
\hline \multicolumn{7}{c}{ CR $=0.0040$} \\
\hline
\end{tabular}

Table A4. Pairwise matrix of sub-criteria with respect to Green Innovation Monitoring.

\begin{tabular}{cccccc}
\hline & D-1 & D-2 & D-3 & D-4 & D-5 \\
\hline D-1 & $1,1,1$ & $0.649,0.913,1.296$ & $0.687,0.944,1.328$ & $0.81,1.144,1.609$ & $0.896,1.272,1.73$ \\
D-2 & $0.771,1.096,1.541$ & $1,1,1$ & $0.687,0.985,1.455$ & $0.728,1,1.373$ & $0.861,1.241,1.747$ \\
D-3 & $0.753,1.059,1.455$ & $0.687,1.015,1.455$ & $1,1,1$ & $0.81,1.144,1.609$ & $0.798,1.043,1.373$ \\
D-4 & $0.622,0.874,1.234$ & $0.728,1,1.373$ & $0.622,0.874,1.234$ & $1,1,1$ & $0.896,1.328,1.896$ \\
D-5 & $0.578,0.786,1.116$ & $0.572,0.806,1.161$ & $0.728,0.958,1.253$ & $0.527,0.753,1.116$ & $1,1,1$ \\
\hline \multicolumn{7}{c}{ CR $=0.0034$} \\
\hline
\end{tabular}




\section{Appendix B}

Table A5. TOPSIS-Grey Decision Matrix.

\begin{tabular}{|c|c|c|c|c|c|c|c|c|c|c|c|c|c|c|c|c|c|c|c|c|}
\hline & A-1 & A-2 & A-3 & A-4 & A-5 & B-1 & B-2 & B-3 & B-4 & B-5 & C-1 & $\mathrm{C}-2$ & C-3 & C-4 & C-5 & D-1 & D-2 & D-3 & D-4 & D-5 \\
\hline Supplier-1 & $\begin{array}{l}4.417 \\
5.833\end{array}$ & $\begin{array}{c}4.083 \\
5.5\end{array}$ & $\begin{array}{l}2.833 \\
4.167\end{array}$ & $\begin{array}{c}5, \\
6.25\end{array}$ & $\begin{array}{c}3.75 \\
5\end{array}$ & $\begin{array}{l}3.5 \\
4.75\end{array}$ & $\begin{array}{l}3.75 \\
5.167\end{array}$ & $\begin{array}{l}4.417 \\
5.833\end{array}$ & $\begin{array}{l}3.833 \\
5.083\end{array}$ & $\begin{array}{r}4.25 \\
5.667\end{array}$ & $\begin{array}{l}3.167 \\
4.583\end{array}$ & $\begin{array}{c}3.917 \\
5.25\end{array}$ & $\begin{array}{r}4.5 \\
5.75\end{array}$ & $\begin{array}{l}5.583 \\
7.333\end{array}$ & $\begin{array}{l}4.333 \\
5.583\end{array}$ & $\begin{array}{r}4.75 \\
5.917\end{array}$ & $\begin{array}{l}4.667 \\
6.083\end{array}$ & $\begin{array}{l}4.833 \\
6.417\end{array}$ & $\begin{array}{l}4.417 \\
5.833\end{array}$ & $\begin{array}{l}3.75 \\
5.167\end{array}$ \\
\hline Supplier-2 & $\begin{array}{l}3.667 \\
4.917\end{array}$ & $\begin{array}{c}4, \\
5.417\end{array}$ & $\begin{array}{c}2.917 \\
4\end{array}$ & $\begin{array}{l}4.167, \\
5.417\end{array}$ & $\begin{array}{l}3.25 \\
4.667\end{array}$ & $\begin{array}{c}3.417 \\
4.75\end{array}$ & $\begin{array}{l}4.083, \\
5.417\end{array}$ & $\begin{array}{r}4.25 \\
5.583\end{array}$ & $\begin{array}{l}3.417 \\
4.667\end{array}$ & $\begin{array}{c}3.917 \\
5.5\end{array}$ & $\begin{array}{l}3.333 \\
4.583\end{array}$ & $\begin{array}{l}3.333 \\
4.667\end{array}$ & $\begin{array}{c}4.083 \\
5.75\end{array}$ & $\begin{array}{l}5.083 \\
6.583\end{array}$ & $\begin{array}{c}3.833 \\
5\end{array}$ & $\begin{array}{l}4.75 \\
6.333\end{array}$ & $\begin{array}{r}4.5 \\
5.917\end{array}$ & $\begin{array}{l}4.583 \\
5.917\end{array}$ & $\begin{array}{c}4 \\
5.25\end{array}$ & $\begin{array}{l}3.75 \\
4.833\end{array}$ \\
\hline Supplier-3 & $\begin{array}{c}4, \\
5.583\end{array}$ & $\begin{array}{r}4.25 \\
5.667\end{array}$ & $\begin{array}{l}3.083 \\
4.333\end{array}$ & $\begin{array}{l}4.636, \\
5.909\end{array}$ & $\begin{array}{l}3.917 \\
5.333\end{array}$ & $\begin{array}{l}3.333 \\
4.667\end{array}$ & $\begin{array}{c}3.917, \\
5.5\end{array}$ & $\begin{array}{l}4.25 \\
5.75\end{array}$ & $\begin{array}{l}3.583 \\
4.833\end{array}$ & $4,5.5$ & $\begin{array}{l}3.25 \\
4.583\end{array}$ & $\begin{array}{l}3.917 \\
5.333\end{array}$ & $\begin{array}{c}4, \\
5.417\end{array}$ & $\begin{array}{c}5.583 \\
7.5\end{array}$ & $\begin{array}{l}4.667 \\
6.167\end{array}$ & & & $\begin{array}{l}5.333 \\
6.833 \\
\end{array}$ & $\begin{array}{c}4.5 \\
5.917\end{array}$ & $\begin{array}{l}4.667, \\
6.083\end{array}$ \\
\hline Supplier-4 & $\begin{array}{c}3.833 \\
5\end{array}$ & $\begin{array}{l}3.667 \\
4.833\end{array}$ & $\begin{array}{c}1.917 \\
3.25\end{array}$ & $\begin{array}{l}3.583, \\
4.833\end{array}$ & $\begin{array}{l}2.917 \\
4.333\end{array}$ & $\begin{array}{c}2.333 \\
3.75\end{array}$ & $\begin{array}{c}3.417, \\
4.75\end{array}$ & $\begin{array}{l}3.667 \\
5.167\end{array}$ & $\begin{array}{l}3.25 \\
4.333\end{array}$ & $\begin{array}{l}3.25 \\
4.75\end{array}$ & $\begin{array}{l}3.417 \\
4.667\end{array}$ & $\begin{array}{l}3.25 \\
4.667\end{array}$ & $\begin{array}{l}3.667 \\
5.167\end{array}$ & $5.5,7$ & $\begin{array}{l}4.167 \\
5.583\end{array}$ & $\begin{array}{l}4.417 \\
5.667\end{array}$ & $\begin{array}{l}3.583 \\
5.083\end{array}$ & $\begin{array}{l}5.25 \\
6.667\end{array}$ & $\begin{array}{l}4.083 \\
5.583\end{array}$ & $\begin{array}{c}3.583, \\
5\end{array}$ \\
\hline Supplier-5 & $\begin{array}{l}3.667 \\
4.917\end{array}$ & $\begin{array}{c}3.417 \\
4.75\end{array}$ & $\begin{array}{l}1.667 \\
3.083\end{array}$ & $\begin{array}{r}3.25 \\
4.417\end{array}$ & $\begin{array}{c}2.667 \\
4\end{array}$ & $\begin{array}{r}2.25 \\
3.583\end{array}$ & $\begin{array}{l}4.083, \\
5.333\end{array}$ & $\begin{array}{c}3.333 \\
4.75\end{array}$ & $\begin{array}{l}3.417 \\
4.833\end{array}$ & $\begin{array}{l}3.083 \\
4.417\end{array}$ & $\begin{array}{l}2.917 \\
4.417\end{array}$ & $\begin{array}{c}3.583 \\
4.75\end{array}$ & $\begin{array}{l}3.75 \\
5.167\end{array}$ & $\begin{array}{c}4.75 \\
6.5\end{array}$ & $\begin{array}{l}3.25, \\
4.75\end{array}$ & $\begin{array}{l}3.917 \\
5.583\end{array}$ & $\begin{array}{c}3.333 \\
4.75\end{array}$ & $\begin{array}{l}4.75 \\
6.167\end{array}$ & $\begin{array}{l}3.917 \\
5.333\end{array}$ & $\begin{array}{l}4.417, \\
5.667\end{array}$ \\
\hline Supplier-6 & $\begin{array}{l}3.667, \\
4.917\end{array}$ & $\begin{array}{r}4.25 \\
5.667\end{array}$ & $\begin{array}{l}3.25 \\
4.75\end{array}$ & $\begin{array}{l}4.333, \\
5.667\end{array}$ & $\begin{array}{c}2.917 \\
4.25\end{array}$ & $\begin{array}{l}3.917 \\
5.333\end{array}$ & $\begin{array}{r}3.25 \\
4.583\end{array}$ & $\begin{array}{l}3.667 \\
5.167\end{array}$ & $\begin{array}{l}4.667 \\
6.083\end{array}$ & $4,5.5$ & $\begin{array}{l}4.583 \\
5.833\end{array}$ & $\begin{array}{l}3.833 \\
5.083\end{array}$ & $\begin{array}{l}4.333 \\
5.833\end{array}$ & $\begin{array}{c}5.75 \\
7.583\end{array}$ & $\begin{array}{l}4.167 \\
5.583\end{array}$ & $\begin{array}{c}3.25, \\
4.5\end{array}$ & $\begin{array}{c}3.167 \\
4.5\end{array}$ & $\begin{array}{l}4.083 \\
5.417\end{array}$ & $\begin{array}{r}4.75 \\
6.167\end{array}$ & $\begin{array}{l}4.333, \\
5.583\end{array}$ \\
\hline
\end{tabular}

Table A6. TOPSIS-Grey Normalized decision matrix.

\begin{tabular}{|c|c|c|c|c|c|c|c|c|c|c|c|c|c|c|c|c|c|c|c|c|}
\hline & A-1 & A-2 & A-3 & A-4 & A-5 & B-1 & $B-2$ & B-3 & $3-4$ & B-5 & $\mathrm{C}-1$ & $C-2$ & $C-3$ & $C-4$ & $C-5$ & D-1 & D-2 & D-3 & D-4 & D-5 \\
\hline $\mathrm{St}$ & $\begin{array}{c}.757, \\
1\end{array}$ & 71 & 877 & 3,1 & 938 & 891 & 939 & $\begin{array}{l}.757 \\
1\end{array}$ & 336 & $\begin{array}{c}0.75 \\
1\end{array}$ & & & & & & & & 79 & $\begin{array}{l}0.716 \\
0.946\end{array}$ & $\begin{array}{l}0.616 \text {, } \\
0.849\end{array}$ \\
\hline Supl & & & & & & & & & & & & & $\begin{array}{c}0.7 \\
0.986\end{array}$ & & & $\begin{array}{c}0.75 \\
1\end{array}$ & & & & \\
\hline er-3 & $\begin{array}{l}0.686 \\
0.957\end{array}$ & $\begin{array}{c}0.75 \\
1\end{array}$ & $\begin{array}{l}0.649 \\
0.912\end{array}$ & $\begin{array}{l}0.742 \\
0.945\end{array}$ & $\begin{array}{c}.734 \\
1\end{array}$ & $\begin{array}{l}0.625 \\
0.875\end{array}$ & $\begin{array}{c}0.712 \\
1\end{array}$ & $\begin{array}{l}729, \\
986\end{array}$ & $\begin{array}{l}0.589 \\
0.795\end{array}$ & & $\begin{array}{l}0.557 \\
0.786\end{array}$ & $\begin{array}{c}0 \\
0.266\end{array}$ & $\begin{array}{c}0.686 \\
0.929\end{array}$ & $\begin{array}{l}0.736 \\
0.989\end{array}$ & $\begin{array}{l}.757, \\
1\end{array}$ & & $\begin{array}{c}.773 \\
1\end{array}$ & $\begin{array}{c}0.78 \\
1\end{array}$ & $\begin{array}{c}0.73 \\
0.959\end{array}$ & $\begin{array}{c}0.767, \\
1\end{array}$ \\
\hline$r-4$ & $\begin{array}{l}0.657 \\
0.857\end{array}$ & 0.853 & 0.684 & $\begin{array}{l}0.573 \\
0.773\end{array}$ & 0.812 & & $\begin{array}{l}0.621 \\
0.864\end{array}$ & & & & $\begin{array}{c}0.586 \\
0.8\end{array}$ & $\begin{array}{l}0.125 \\
0.391\end{array}$ & $\begin{array}{l}0.629 \\
0.886\end{array}$ & $\begin{array}{l}0.725 \\
0.923\end{array}$ & & & & & & $\begin{array}{l}0.589, \\
0.822\end{array}$ \\
\hline$r-5$ & $\begin{array}{l}0.629 \\
0.843\end{array}$ & $\begin{array}{l}0.603 \\
0.838\end{array}$ & $\begin{array}{l}0.351 \\
0.649\end{array}$ & $\begin{array}{c}0.52 \\
0.707\end{array}$ & $\begin{array}{l}0.5, \\
0.75\end{array}$ & $\begin{array}{l}0.422 \\
0.672\end{array}$ & $\begin{array}{c}0.742 \\
0.97\end{array}$ & $\begin{array}{l}0.571 \\
0.814\end{array}$ & $\begin{array}{l}562, \\
795\end{array}$ & $\begin{array}{l}.544, \\
.779\end{array}$ & $\begin{array}{c}0.5 \\
0.757\end{array}$ & $\begin{array}{l}0.109 \\
0.328\end{array}$ & $\begin{array}{l}0.643 \\
0.886\end{array}$ & $\begin{array}{l}0.626 \\
0.857\end{array}$ & $\begin{array}{c}0.527 \\
0.77\end{array}$ & $\begin{array}{l}0.618 \\
0.882\end{array}$ & $\begin{array}{c}0.533 \\
0.76\end{array}$ & $\begin{array}{l}0.695 \\
0.902\end{array}$ & $\begin{array}{l}0.635 \\
0.865\end{array}$ & $\begin{array}{l}0.726, \\
0.932\end{array}$ \\
\hline Supplier-6 & $\begin{array}{l}0.629 \\
0.843\end{array}$ & $\begin{array}{c}0.75 \\
1\end{array}$ & $\begin{array}{c}0.684 \\
1\end{array}$ & $\begin{array}{l}0.693 \\
0.907\end{array}$ & $\begin{array}{l}0.547 \\
0.797\end{array}$ & $\begin{array}{c}0.734 \\
1\end{array}$ & $\begin{array}{l}0.591 \\
0.833\end{array}$ & $\begin{array}{l}0.629 \\
0.886\end{array}$ & $\begin{array}{c}0.767 \\
1\end{array}$ & $\begin{array}{l}0.706 \\
0.971\end{array}$ & $\begin{array}{c}0.786 \\
1\end{array}$ & $\begin{array}{l}0.047 \\
0.281\end{array}$ & $\begin{array}{c}0.743 \\
1\end{array}$ & $\begin{array}{c}0.758 \\
1\end{array}$ & $\begin{array}{l}0.676 \\
0.905\end{array}$ & $\begin{array}{l}0.513 \\
0.711\end{array}$ & $\begin{array}{c}0.507 \\
0.72\end{array}$ & $\begin{array}{l}0.598 \\
0.793\end{array}$ & $\begin{array}{c}0.77 \\
1\end{array}$ & $\begin{array}{l}0.712, \\
0.918\end{array}$ \\
\hline
\end{tabular}


Table A7. Positive ideal and negative ideal solution.

\begin{tabular}{cccccccccccccccccccccccc}
\hline & A-1 & A-2 & A-3 & A-4 & A-5 & B-1 & B-2 & B-3 & B-4 & B-5 & C-1 & C-2 & C-3 & C-4 & C-5 & D-1 & D-2 & D-3 & D-4 & D-5 \\
\hline A+ & 1 & 1 & 1 & 1 & 1 & 1 & 1 & 1 & 1 & 1 & 1 & 0 & 1 & 1 & 1 & 1 & 1 & 1 & 1 & 1 \\
A- & 0.629 & 0.603 & 0.351 & 0.52 & 0.5 & 0.422 & 0.591 & 0.571 & 0.534 & 0.544 & 0.5 & 0.391 & 0.629 & 0.626 & 0.527 & 0.513 & 0.507 & 0.598 & 0.635 & 0.589 \\
\hline
\end{tabular}

Table A8. Positive ideal solution $(\mathrm{d}+)$.

\begin{tabular}{|c|c|c|c|c|c|c|c|c|c|c|c|c|c|c|c|c|c|c|c|c|}
\hline & A-1 & A-2 & A-3 & A-4 & A-5 & B-1 & B-2 & B-3 & B-4 & B-5 & C-1 & C-2 & C-3 & C-4 & C-5 & D-1 & D-2 & D-3 & D-4 & D-5 \\
\hline Supp & 0.003 & 0.004 & 0.009 & 002 & 004 & 007 & 006 & 003 & 008 & 003 & 012 & 0.008 & 0.003 & .004 & 0.004 & 0.004 & 0.003 & 0.005 & 0.004 & 0.007 \\
\hline Supp & 0.008 & 0.004 & 0.009 & 0.006 & 0.008 & 08 & 04 & 04 & 13 & 04 & 11 & 0.004 & 0.005 & 0.007 & 0.008 & 0.003 & 0.004 & 0.007 & .007 & 0.008 \\
\hline Supplier-3 & 0.005 & 0.003 & 0.007 & 0.003 & 0.003 & 0.009 & 0.004 & 0.004 & 0.011 & 0.004 & 0.012 & 0.009 & 0.005 & 0.004 & 0.003 & 0.004 & 0.003 & 0.003 & 0.004 & 0.002 \\
\hline Supplier-4 & 0.007 & 0.007 & 0.023 & 0.01 & 0.011 & 0.023 & 0.009 & 0.008 & 0.015 & 0.009 & 0.01 & 0.004 & 0.008 & 0.004 & 0.005 & 0.005 & 0.012 & 0.003 & 0.006 & 0.009 \\
\hline & 0.008 & 0.009 & 0.027 & 0.014 & 0.015 & 0.025 & 0.004 & $0 .($ & 0 & 0.012 & 0.015 & 0.004 & 0.007 & 0.008 & 0.012 & 0.008 & 0.015 & 0.005 & 0.008 & 0.003 \\
\hline Supplier-6 & 0.008 & 0.003 & 0.005 & 0.005 & 0.012 & 0.004 & 0.01 & 0.008 & 0.003 & 0.004 & 0.002 & 0.007 & 0.003 & 0.003 & 0.005 & 0.017 & 0.017 & 0.011 & 0.003 & 0.004 \\
\hline
\end{tabular}

Table A9. Negative ideal solution (d-).

\begin{tabular}{ccccccccccccccccccccc}
\hline & A-1 & A-2 & A-3 & A-4 & A-5 & B-1 & B-2 & B-3 & B-4 & B-5 & C-1 & C-2 & C-3 & C-4 & C-5 & D-1 & D-2 & D-3 & D-4 & D-5 \\
\hline Supplier-1 & 0.008 & 0.008 & 0.017 & 0.014 & 0.011 & 0.016 & 0.007 & 0.011 & 0.005 & 0.011 & 0.004 & 0.004 & 0.008 & 0.007 & 0.008 & 0.012 & 0.015 & 0.007 & 0.005 & 0.003 \\
Supplier-2 & 0.002 & 0.007 & 0.016 & 0.006 & 0.007 & 0.015 & 0.009 & 0.009 & 0.003 & 0.009 & 0.004 & 0.008 & 0.007 & 0.003 & 0.004 & 0.015 & 0.013 & 0.004 & 0.002 & 0.002 \\
Supplier-3 & 0.006 & 0.009 & 0.02 & 0.01 & 0.014 & 0.014 & 0.01 & 0.01 & 0.004 & 0.009 & 0.004 & 0.004 & 0.005 & 0.007 & 0.012 & 0.013 & 0.017 & 0.01 & 0.006 & 0.009 \\
Supplier-4 & 0.003 & 0.003 & 0.006 & 0.003 & 0.005 & 0.005 & 0.004 & 0.005 & 0.002 & 0.004 & 0.005 & 0.009 & 0.003 & 0.005 & 0.007 & 0.009 & 0.005 & 0.009 & 0.004 & 0.002 \\
Supplier-5 & 0.002 & 0.003 & 0.004 & 0.002 & 0.003 & 0.004 & 0.009 & 0.003 & 0.004 & 0.003 & 0.003 & 0.006 & 0.003 & 0.003 & 0.003 & 0.008 & 0.003 & 0.005 & 0.003 & 0.006 \\
Supplier-6 & 0.002 & 0.009 & 0.027 & 0.008 & 0.004 & 0.025 & 0.003 & 0.005 & 0.014 & 0.009 & 0.016 & 0.004 & 0.008 & 0.008 & 0.007 & 0.002 & 0.002 & 0.002 & 0.008 & 0.005 \\
\hline
\end{tabular}




\section{References}

1. Knap, A.H.; Rusyn, I. Environmental Exposures Due to Natural Disasters. Rev. Environ. Health 2016, 31 , 89-92. [CrossRef] [PubMed]

2. Stocker, T.F.; Qin, D.; Plattner, G.K.; Tignor, M.M.B.; Allen, S.K.; Boschung, J.; Nauels, A.; Xia, Y.; Bex, V.; Midgley, P.M. Climate Change 2013 the Physical Science Basis: Working Group I Contribution to the Fifth Assessment Report of the Intergovernmental Panel on Climate Change. 2013, Volume 9781107057. Available online: https://www.ipcc.ch/report/ar5/wg1/ (accessed on 10 March 2020).

3. Ghisetti, C.; Mancinelli, S.; Mazzanti, M.; Zoli, M. Financial Barriers and Environmental Innovations: Evidence from EU Manufacturing Firms. Clim. Policy 2017, 17 (Suppl. 1), S131-S147. [CrossRef]

4. Pachauri; Rajendra, K.M.; Leo, V.Y.; Jean-Pascal, B.; Sander, V.K.; Line, L.-R.; Noëmie, V.B. Climate Change 2014: Synthesis Report. Contribution of Working Groups I, II and III to the Fifth Assessment Report of the Intergovernmental Panel on Climate Change. 2014. Available online: https://www.ipcc.ch/report/ar5/syr/ (accessed on 10 March 2020).

5. The Sustainable Development Goals Report 2016; United Nations: New York, NJ, USA, 2016; Available online: https://www.un.org/development/desa/publications/sustainable-development-goals-report-2016. html (accessed on 10 March 2020).

6. Shah, S.A.A.; Solangi, Y.A. A Sustainable Solution for Electricity Crisis in Pakistan: Opportunities, Barriers, and Policy Implications for 100\% Renewable Energy. Environ. Sci. Pollut. Res. 2019, 26, 29687-29703. [CrossRef] [PubMed]

7. Somsuk, N.; Laosirihongthong, T. Prioritization of Applicable Drivers for Green Supply Chain Management Implementation toward Sustainability in Thailand. Int. J. Sustain. Dev. World Ecol. 2017, 24, 175-191. [CrossRef]

8. Gurtu, A.; Searcy, C.; Jaber, M.Y. Sustainable Supply Chains. In Green Supply Chain Management for Sustainable Business Practice; IGI Global: Hershey, PA, USA, 2016; pp. 1-26.

9. Chang, C.H.; Chen, Y.S. Green Organizational Identity and Green Innovation. Manag. Decis. 2013, 51, 1056-1070. [CrossRef]

10. dos Santos, B.M.; Godoy, L.P.; Campos, L.M.S. Performance Evaluation of Green Suppliers Using Entropy-TOPSIS-F. J. Clean. Prod. 2019, 207, 498-509. [CrossRef]

11. Fahimnia, B.; Sarkis, J.; Davarzani, H. Green Supply Chain Management: A Review and Bibliometric Analysis. Int. J. Prod. Econ. 2015, 162, 101-114. [CrossRef]

12. Konys, A. Green Supplier Selection Criteria: From a Literature Review to a Comprehensive Knowledge Base. Sustainability 2019, 11, 4208. [CrossRef]

13. Zhu, Q.; Sarkis, J.; Lai, K. hung. Green Supply Chain Management: Pressures, Practices and Performance within the Chinese Automobile Industry. J. Clean. Prod. 2007, 15, 1041-1052. [CrossRef]

14. Mohammed, A.; Harris, I.; Soroka, A.; Nujoom, R. A Hybrid MCDM-Fuzzy Multi-Objective Programming Approach for a G-Resilient Supply Chain Network Design. Comput. Ind. Eng. 2019, 127, 297-312. [CrossRef]

15. Hong, Z.; Guo, X. Green Product Supply Chain Contracts Considering Environmental Responsibilities. Omega 2019, 83, 155-166. [CrossRef]

16. Solangi, Y.A.; Tan, Q.; Mirjat, N.H.; Ali, S. Evaluating the Strategies for Sustainable Energy Planning in Pakistan: An Integrated SWOT-AHP and Fuzzy-TOPSIS Approach. J. Clean. Prod. 2019, 236, 117655. [CrossRef]

17. Xu, L.; Shah, S.A.A.; Zameer, H.; Solangi, Y.A. Evaluating Renewable Energy Sources for Implementing the Hydrogen Economy in Pakistan: A Two-Stage Fuzzy MCDM Approach. Environ. Sci. Pollut. Res. 2019, 26, 33202-33215. [CrossRef] [PubMed]

18. Wang, Y.; Xu, L.; Solangi, Y.A. Strategic Renewable Energy Resources Selection for Pakistan: Based on SWOT-Fuzzy AHP Approach. Sustain. Cities Soc. 2020, 52, 101861. [CrossRef]

19. Musaad, O.; Sultan, A.; Zhuo, Z.; Musaad, O.; Otaibi, A.; Siyal, Z.A.; Hashmi, H.; Shah, S.A.A. A Fuzzy Multi-Criteria Analysis of Barriers and Policy Strategies for Small and Medium Enterprises to Adopt Green Innovation. Symmetry 2020, 12, 116. [CrossRef]

20. Luthra, S.; Govindan, K.; Kannan, D.; Mangla, S.K.; Garg, C.P. An Integrated Framework for Sustainable Supplier Selection and Evaluation in Supply Chains. J. Clean. Prod. 2017, 140, 1686-1698. [CrossRef] 
21. Rezaei, J.; Nispeling, T.; Sarkis, J.; Tavasszy, L. A Supplier Selection Life Cycle Approach Integrating Traditional and Environmental Criteria Using the Best Worst Method. J. Clean. Prod. 2016, 135, 577-588. [CrossRef]

22. Awasthi, A.; Kannan, G. Green Supplier Development Program Selection Using NGT and VIKOR under Fuzzy Environment. Comput. Ind. Eng. 2016, 91, 100-108. [CrossRef]

23. Hashemi, S.H.; Karimi, A.; Tavana, M. An Integrated Green Supplier Selection Approach with Analytic Network Process and Improved Grey Relational Analysis. Int. J. Prod. Econ. 2015, 159, 178-191. [CrossRef]

24. Tsui, C.W.; Wen, U.P. A Hybrid Multiple Criteria Group Decision-Making Approach for Green Supplier Selection in the TFT-LCD Industry. Math. Probl. Eng. 2014, 2014, 709872. [CrossRef]

25. Hsu, C.W.; Kuo, T.C.; Chen, S.H.; Hu, A.H. Using DEMATEL to Develop a Carbon Management Model of Supplier Selection in Green Supply Chain Management. J. Clean. Prod. 2013, 56, 164-172. [CrossRef]

26. Akman, G. Evaluating Suppliers to Include Green Supplier Development Programs via Fuzzy C-Means and VIKOR Methods. Comput. Ind. Eng. 2015, 86, 69-82. [CrossRef]

27. Zafar, A.; Zafar, M.; Sarwar, A.; Raza, H.; Khan, M.T. A Fuzzy AHP Method for Green Supplier Selection and Evaluation. In Proceedings of the International Conference on Management Science and Engineering Management, Ontario, ON, Canada, 5-8 August 2019; Springer: Berlin/Heidelberg, Germany, 2019; pp. 1355-1366.

28. Sharma, D.G.; Rawani, A.M. Green Supplier Selection for Indian Cement Industry: AHP Based Approach. Int. Res. J. Eng. Technol. 2016, 2368-2373.

29. Banaeian, N.; Mobli, H.; Fahimnia, B.; Nielsen, I.E.; Omid, M. Green Supplier Selection Using Fuzzy Group Decision Making Methods: A Case Study from the Agri-Food Industry. Comput. Oper. Res. 2018, 89, 337-347. [CrossRef]

30. Lin, R.H. An Integrated Model for Supplier Selection under a Fuzzy Situation. Int. J. Prod. Econ. 2012, 138, 55-61. [CrossRef]

31. Chan, F.T.S.; Kumar, N.; Tiwari, M.K.; Lau, H.C.W.; Choy, K.L. Global Supplier Selection: A Fuzzy-AHP Approach. Int. J. Prod. Res. 2008, 46, 3825-3857. [CrossRef]

32. Chen, C.T.; Lin, C.T.; Huang, S.F. A Fuzzy Approach for Supplier Evaluation and Selection in Supply Chain Management. Int. J. Prod. Econ. 2006, 102, 289-301. [CrossRef]

33. Hussain, M.; Al-Aomar, R. A Model for Assessing the Impact of Sustainable Supplier Selection on the Performance of Service Supply Chains. Int. J. Sustain. Eng. 2018, 11, 366-381. [CrossRef]

34. Kannan, D.; De Sousa Jabbour, A.B.L.; Jabbour, C.J.C. Selecting Green Suppliers Based on GSCM Practices: Using Fuzzy TOPSIS Applied to a Brazilian Electronics Company. Eur. J. Oper. Res. 2014, 233, $432-447$. [CrossRef]

35. Govindan, K.; Rajendran, S.; Sarkis, J.; Murugesan, P. Multi Criteria Decision Making Approaches for Green Supplier Evaluation and Selection: A Literature Review. J. Clean. Prod. 2015, 98, 66-83. [CrossRef]

36. Haeri, S.A.S.; Rezaei, J. A Grey-Based Green Supplier Selection Model for Uncertain Environments. J. Clean. Prod. 2019, 221, 768-784. [CrossRef]

37. Fallahpour, A.; Olugu, E.U.; Musa, S.N.; Khezrimotlagh, D.; Wong, K.Y. An Integrated Model for Green Supplier Selection under Fuzzy Environment: Application of Data Envelopment Analysis and Genetic Programming Approach. Neural Comput. Appl. 2016, 27, 707-725. [CrossRef]

38. Shabanpour, H.; Yousefi, S.; Saen, R.F. Forecasting Efficiency of Green Suppliers by Dynamic Data Envelopment Analysis and Artificial Neural Networks. J. Clean. Prod. 2017, 142, 1098-1107. [CrossRef]

39. Govindan, K.; Sivakumar, R. Green Supplier Selection and Order Allocation in a Low-Carbon Paper Industry: Integrated Multi-Criteria Heterogeneous Decision-Making and Multi-Objective Linear Programming Approaches. Ann. Oper. Res. 2016, 238, 243-276. [CrossRef]

40. Cucchiella, F.; D’Adamo, I. Issue on Supply Chain of Renewable Energy. Energy Convers. Manag. 2013, 76, 774-780. [CrossRef]

41. Awasthi, A.; Govindan, K.; Gold, S. Multi-Tier Sustainable Global Supplier Selection Using a Fuzzy AHP-VIKOR Based Approach. Int. J. Prod. Econ. 2018, 195, 106-117. [CrossRef]

42. Zameer, H.; Wang, Y.; Yasmeen, H. Reinforcing Green Competitive Advantage through Green Production, Creativity and Green Brand Image: Implications for Cleaner Production in China. J. Clean. Prod. 2020, 247, 119119. [CrossRef] 
43. Oroojeni Mohammad Javad, M.; Darvishi, M. Green Supplier Selection for the Steel Industry Using BWM and Fuzzy TOPSIS: A Case Study of Khouzestan Steel Company. Sustain. Futures 2020, 2, 100012. [CrossRef]

44. Hsu, C.W.; Hu, A.H. Applying Hazardous Substance Management to Supplier Selection Using Analytic Network Process. J. Clean. Prod. 2009, 17, 255-264. [CrossRef]

45. Wang, Z.; Mathiyazhagan, K.; Xu, L.; Diabat, A. A Decision Making Trial and Evaluation Laboratory Approach to Analyze the Barriers to Green Supply Chain Management Adoption in a Food Packaging Company. J. Clean. Prod. 2016, 117, 19-28. [CrossRef]

46. Shi, H.; Quan, M.Y.; Liu, H.C.; Duan, C.Y. A Novel Integrated Approach for Green Supplier Selection with Interval-Valued Intuitionistic Uncertain Linguistic Information: A Case Study in the Agri-Food Industry. Sustainability 2018, 10, 733. [CrossRef]

47. Lee, E.K.; Ha, S.; Kim, S.K. Supplier Selection and Management System Considering Relationships in Supply Chain Management. IEEE Trans. Eng. Manag. 2001, 48, 307-318.

48. Saaty, T.L. The Analytic Hierarchy Process; McGrawHill: New York, NY, USA, 1990; Volume 45. Available online: https://www.sciencedirect.com/science/article/abs/pii/037722179090057I (accessed on 10 March 2020).

49. Zadeh, L.A. Fuzzy Sets as a Basis for a Theory of Possibility. Fuzzy Sets Syst. 1978, 1, 3-28. [CrossRef]

50. Solangi, Y.A.; Shah, S.A.A.; Zameer, H.; Ikram, M.; Saracoglu, B.O. Assessing the Solar PV Power Project Site Selection in Pakistan: Based on AHP-Fuzzy VIKOR Approach. Environ. Sci. Pollut. Res. 2019, 26, 30286-30302. [CrossRef]

51. Chang, D.-Y. Applications of the Extent Analysis Method on Fuzzy AHP. Eur. J. Oper. Res. 1996, 95, 649-655. [CrossRef]

52. Hwang, C.-L.; Yoon, K. Multiple Criteria Decision Making. Lect. Notes Econ. Math. Syst. 1981, 186, 58-191.

53. Xu, L.; Wang, Y.; Shah, S.A.A.; Zameer, H.; Solangi, Y.A.; Das Walasai, G.; Siyal, Z.A. Economic Viability and Environmental Efficiency Analysis of Hydrogen Production Processes for the Decarbonization of Energy Systems. Processes 2019, 7, 494. [CrossRef]

54. Shah, S.A.A. Feasibility Study of Renewable Energy Sources for Developing the Hydrogen Economy in Pakistan. Int. J. Hydrog. Energy 2019, in press. [CrossRef]

55. Zavadskas, E.K.; Vilutienė, T.; Turskis, Z.; Tamosaitienè, J. Contractor Selection for Construction Works By Applying Saw-G and Topsis Grey Techniques. J. Bus. Econ. Manag. 2010, 11, 34-55. [CrossRef]

56. Deng, J. Introduction to Grey Theory. J. Grey Syst. 1989, 1, 1-24.

57. Oztaysi, B. A Decision Model for Information Technology Selection Using AHP Integrated TOPSIS-Grey: The Case of Content Management Systems. Knowl. -Based Syst. 2014, 70, 44-54. [CrossRef]

58. Shah, S.A.A.; Solangi, Y.A.; Ikram, M. Analysis of Barriers to the Adoption of Cleaner Energy Technologies in Pakistan Using Modified Delphi and Fuzzy Analytical Hierarchy Process. J. Clean. Prod. 2019, 235, 1037-1050. [CrossRef]

59. Gupta, H.; Barua, M.K. Supplier Selection among SMEs on the Basis of Their Green Innovation Ability Using BWM and Fuzzy TOPSIS. J. Clean. Prod. 2017, 152, 242-258. [CrossRef]

60. Toloo, M.; Nalchigar, S. A New DEA Method for Supplier Selection in Presence of Both Cardinal and Ordinal Data. Expert Syst. Appl. 2011, 38, 14726-14731. [CrossRef]

61. Wu, H.H.; Chang, S.Y. A Case Study of Using DEMATEL Method to Identify Critical Factors in Green Supply Chain Management. Appl. Math. Comput. 2015, 256, 394-403. [CrossRef] 